\title{
Transformaciones urbanas y de la estructura social de un barrio de la ciudad de Buenos Aires
}

\section{Urban transformations and transformations of the social structure of a neighborhood in the City of Buenos Aires}

LUIS BAER*

\begin{abstract}
Some scholars tace the urban processes that restate the structure, soil use and city landscape; some others analyze the effect of these changes on the life conditions, collective practices and social representations. This work tries to be halfway the aforementioned perceptions; we account the urban interventions which restructured a neighborhood in the city of Buenos Aires between 1998 and 2004, namely del Abasto neighborhood. This transformation was fostered by the private sector and it consisted of the adaptation of large urban sites for commercial, residential and leisure uses. We researched the urban changes from the quotidian practices and representations of the residents of the Torres de Abasto, a group of people who moved in the neighborhood when its reconversion had already begun. We analyzed the links and representations which are established in said residential complex and in the surrounding neighborhood.
\end{abstract}

Keywords: urban transformation; practices and representations of quotidian life; del Abasto neighborhood; Torres de Abasto.

\section{Resumen}

Algunos estudios abordan los procesos urbanos que replantean la estructura, los usos del suelo y el paisaje de la ciudad; otros analizan los efectos de estos cambios en las condiciones de vida, las prácticas colectivas y las representaciones sociales. Este trabajo intenta ubicarse entre ambas perspectivas. Recorremos las intervenciones urbanas que reestructuraron un barrio de la ciudad de Buenos Aires entre 1998 y 2004, el barrio del Abasto. Esta transformación la impulsó el sector privado y consistió en el acondicionamiento de grandes emplazamientos urbanos para usos comerciales, residenciales y de entretenimiento. Investigamos los cambios urbanos desde las prácticas y representaciones cotidianas de los residentes de las Torres de Abasto, un grupo de personas que se mudó al barrio cuando ya había comenzado su reconversión. Analizamos los vínculos y las representaciones que se establecen en dicho complejo residencial y en el barrio que lo rodea.

Palabras clave: transformaciones urbanas, prácticas y representaciones de la vida cotidiana, barrio del Abasto, Torres de Abasto.

*Universidad de Buenos Aires, Argentina. Correo-e: luisbaer@yahoo.com.ar. 


\section{Algunas lógicas y actores de las transformaciones urbanas recientes en Buenos Aires ${ }^{1}$}

\subsection{Procesos económicos y desarrollo urbano}

Existen diversos trabajos que analizan los procesos actuales de reestructuración urbana en relación con las transformaciones que experimenta la economía mundial. Las tendencias de localización de los flujos de inversión, así como el avance de las nuevas tecnologías de información y comunicación son algunos de los ejes más problematizados para investigar los vínculos entre ambas dimensiones. ${ }^{2}$ Independientemente del tema y la perspectiva adoptada para abordar la interacción de los procesos urbanos y económicos contemporáneos, lo cierto es que en la bibliografía consultada se identifica que los actores económicos de mayor peso internacional operan cada vez más a escala global, orientando sus inversiones a ciudades (o algunas de sus áreas) con condiciones económicas, políticas y de infraestructura que garanticen al máximo la rentabilidad y al mínimo los riesgos de inversión.

En este contexto, las ciudades compiten entre sí promocionando sus ventajas comparativas y adaptando las estructuras y funciones del territorio para atraer inversiones e insertarse de la mejor manera posible en la nueva red jerárquica de ciudades globales. Como consecuencia de la mayor o menor articulación de las ciudades a la red global de relaciones económicas, se configuró un modelo selectivo de inclusión y exclusión de territorios urbanos en materia de atracción de capitales. Los espacios metropolitanos se consolidan como espacios de la crisis global y, al mismo tiempo, como espacios donde las decisiones, la información y los flujos de capital se concentran de manera creciente (Ciccolella, 2006). En relación con estos procesos económicos y territoriales se redefine también el poder de acción de los actores involucrados en el desarrollo urbano. Grandes cambios morfológicos y funcionales de las ciudades ahora los produce el sector privado, en numerosas ocasiones a cargo de empresas transnacionales interesadas en destinar sus recursos al negocio inmobiliario y a la producción de servicios públicos. Como contrapartida, el Estado fue relegando su participación en la planificación territorial al transferir a las empresas privadas gran parte de la prestación de infraestructura y servicios urbanos.

\footnotetext{
${ }^{1}$ Este artículo es una versión sintetizada y mejorada de la tesis de licenciatura terminada en diciembre de 2004.

${ }^{2}$ Algunos de los textos más citados en este tema son Harvey (1990), Sassen (1991), Veltz (1994) y Borja y Castells (1997).
} 
De acuerdo con los dictámenes de los organismos internacionales de crédito, en América Latina este proceso de privatización tuvo una tímida o nula presencia estatal en la regulación del mercado, hecho que permitió que la empresa privada gestionara sus proyectos bajo el precepto único de incrementar la ganancia. Al respecto, Ciccolella y Mignaqui (2008) identifican que los Estados latinoamericanos han tenido serias dificultades para desarrollar formas eficaces de intervención en el espacio urbano, y que el factor de transformación metropolitana más decisivo respondió a los lineamientos de un proyecto urbano hegemónico a cargo sobre todo del capital financiero e inmobiliario.

El repliegue del Estado y la mayor injerencia del sector privado en la planeación y desarrollo urbano de la Región Metropolitana de Buenos Aires (RмBA) desencadenaron diversos efectos territoriales y sociales. ${ }^{3}$ Durante los noventa, la privatización de numerosas empresas públicas se tradujo en la pérdida de control estatal en materia de producción de servicios y suelo urbano (Pírez, 2006). Esta coyuntura posibilitó el aprovechamiento de las inversiones públicas realizadas a lo largo de la historia de la ciudad para generar y acumular capital privado (Gorelik, 1994).

Las inversiones extranjeras también han fomentado la construcción de grandes complejos comerciales. Además de provocar el cierre de numerosos comercios pequeños y medianos, el acondicionamiento de grandes superficies del espacio urbano para el desarrollo de diversas prácticas de consumo ha contribuido a transformar la vida urbana porteña. La declinación del uso colectivo del espacio público y el incremento del empleo masivo de grandes centros comerciales es uno de los principales exponentes de dicho cambio. Algunos criterios tradicionales que permitieron alguna vez demarcar la esfera de lo público y lo privado (la forma de tenencia y el tipo de apropiación) también han caducado. Numerosos emplazamientos urbanos son de propiedad privada pero tienen utilidad pública porque cualquier persona puede acceder a ellos mientras no transgreda las normas del lugar. Quizás sea el shopping center, en sus múltiples tipos y tamaños, el principal referente de esta modalidad de apropiación pública de un bien privado. Y lo mismo ocurre a la inversa. Ciertos espacios de propiedad estatal cada vez más están a cargo del sector privado. El mantenimiento de las plazas y la vigilancia de algunos barrios

\footnotetext{
${ }^{3}$ RMBA se utiliza para el conjunto del aglomerado urbano que comprende las siguientes zonas: a) Ciudad Autónoma de Buenos Aires (CBA), con un área de $200 \mathrm{~km}^{2}$ y una población actual aproximada de 3'100,000 habitantes; b) Gran Buenos Aires (GBA), conformada por 24 partidos (departamentos o municipios) que forman la primera y segunda corona de la aglomeración, con un área de $3,680 \mathrm{~km}^{2}$ y una población actual aproximada de nueve millones de habitantes; y c) el resto de la RMBA, o tercera corona, integrada por 16 partidos con un área aproximada de $15,800 \mathrm{~km}^{2}$ y una población actual de 1.6 millones de habitantes (figura 1). En conjunto, la RMBA comprende un área de $19,680 \mathrm{~km}^{2}$ y una población actual aproximada de 13.7 millones de habitantes.
} 


\section{Figura 1}

\section{Región Metropolitana de Buenos Aires}

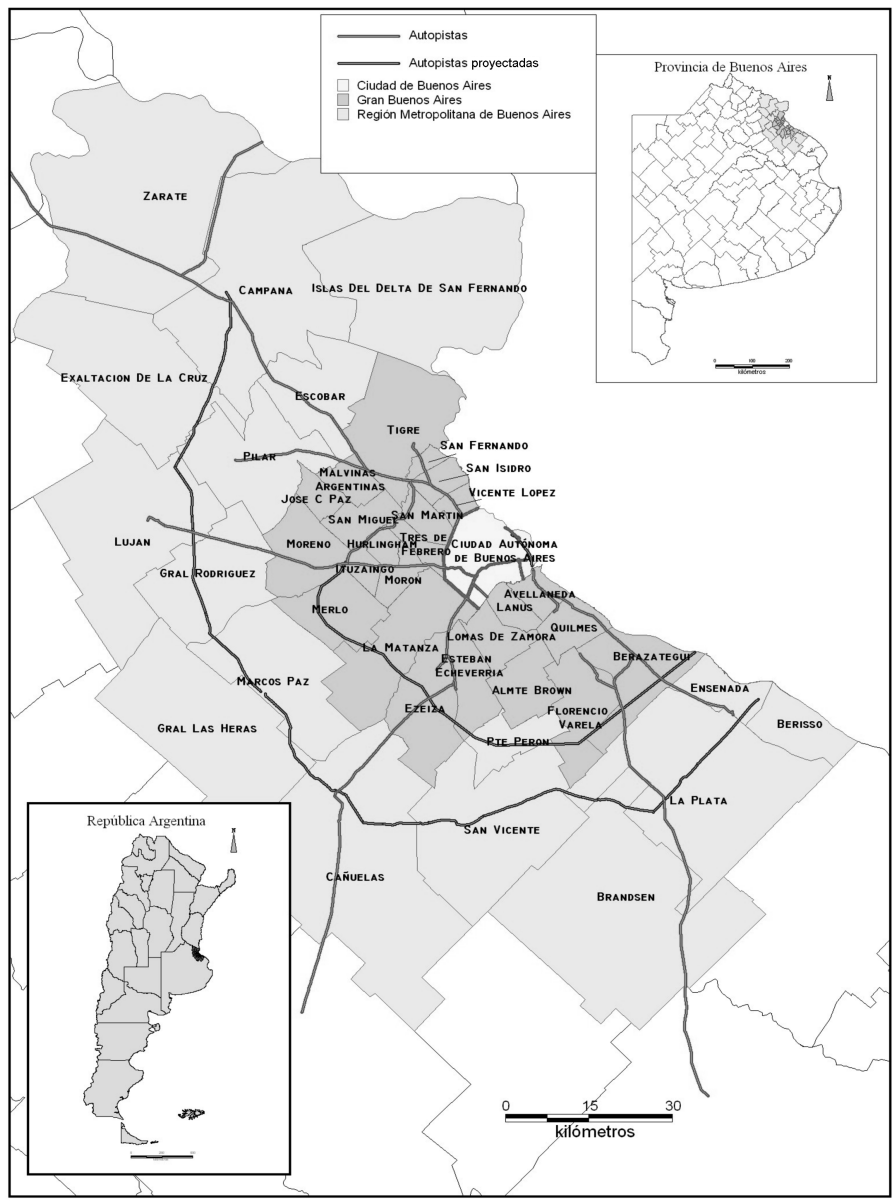

Fuente: Elaborado por Marianela Figueroa para el Programa de Estudios sobre Desarrollo Territorial y Estudios Metropolitanos (PDTEM), Instituto de Geografía (UBA). 
residenciales administrados por empresas privadas ejemplifican esta intromisión del sector privado en la esfera tradicional de lo público.

La retirada del Estado en la gestión urbana y, como contrapartida, la mayor injerencia del sector privado en el desarrollo del territorio también reforzó la desigualdad socioterritorial preexistente. Las inversiones privadas se volcaron sobre todo a las funciones de consumo mencionadas, de servicios especializados ${ }^{4} \mathrm{y}$ a la construcción de nuevas modalidades habitacionales. Algunos proyectos territoriales impulsados por estas inversiones son los grandes complejos comerciales, los edificios inteligentes de oficinas, los hoteles de alta gama, los parques de diversiones, las grandes cadenas de cines y los diferentes tipos de urbanizaciones cerradas. Estos nuevos conjuntos habitacionales y de consumo fueron los mayores demandantes y beneficiarios de la extensión y mejoramiento de la infraestructura de transporte, especialmente de las nuevas autopistas que fomentaron el incremento del uso del automóvil (Ciccolella, 2000). Pero las diferentes condiciones estructurales para atraer y beneficiarse de los flujos económicos han provocado que sólo algunas zonas y corredores urbanos lograran beneficiarse de la infraestructura de servicios, los grandes centros de consumo y las nuevas alternativas residenciales producidas por la lógica del sector privado. La falta de recursos y políticas públicas para contrarrestar la inequidad que produce la dinámica del mercado en el desarrollo urbano profundizó la histórica fragmentación socioterritorial de la ciudad. Junto con la aparición de enclaves urbanos con novedosos materiales, tecnologías y diseños, en la mayor parte de la ciudad se deterioraron las viviendas, la infraestructura y los servicios urbanos y, por tanto, las condiciones de vida de gran parte de la población de la ciudad. En suma, a la histórica segregación socioterritorial se le agrega ahora la ciudad de los marginados de un desarrollo urbano ideado por un modelo político-económico inaugurado hace tres décadas y fortalecido en los años noventa. ${ }^{5}$

\subsection{Nuevas experiencias de la vida urbana: las urbanizaciones y los edificios cercados}

El crecimiento de la pobreza, su correlación con la inseguridad y el deterioro del equipamiento y la infraestructura urbana, sentaron las condi-

\footnotetext{
${ }^{4}$ Varios de ellos vinculados a los llamados servicios distributivos (transportes y comunicación) y a los servicios productivos (bancos, seguros, ingeniería y contabilidad, entre otros).

${ }^{5}$ Algunos lineamientos del modelo político-económico de las últimas décadas a destacar son la reestructuración y disminución del Estado, la privatización de servicios públicos, la estabilización monetaria y la flexibilización laboral, entre otras medidas afines a los intereses de los grandes grupos de inversión y del capital financiero que aumentaron la inequidad social y territorial mencionada.
} 
ciones para que los estratos socioeconómicos altos y medios ${ }^{6}$ prefirieran una atmósfera urbana diferente a la decadencia que atravesaba la mayor parte del territorio metropolitano. En este contexto de descomposición social y declive del espacio urbano se construyeron diferentes tipos de urbanizaciones cerradas. ${ }^{7}$ La demanda creciente de espacios residenciales seguros, cercados, con equipamiento y servicios de calidad por parte de la población de mayores ingresos fue atendida por un conjunto variado de actores económicos (desarrolladores inmobiliarios, empresas de construcción, estudios contables, grupos de inversores y diseñadores urbanos). Comenzaron así a extenderse diversos tipos de urbanizaciones cerradas a lo largo de los principales corredores metropolitanos, especialmente en la zona norte de la RMBA. La necesidad de pertenecer a otra ciudad cercenó aún más las posibilidades de desarrollar una Buenos Aires más abierta, inclusiva y con participación colectiva e interacción entre los diferentes estratos sociales.

La aparición de la primera urbanización cerrada en la periferia de la ciudad ocurrió en la década de los ańos treinta, cuando surge la modalidad del country club. Se trata de un predio cerrado con viviendas para uso de fin de semana y con instalaciones para desarrollar actividades deportivas y recreativas. A finales de los ochenta las urbanizaciones cerradas tuvieron un desarrollo sin precedentes en el proceso de suburbanización de la RMBA. La nueva tendencia la impulsa una expansión significativa de barrios privados en el Gran Buenos Aires, específicamente en el transcurso de la segunda mitad de los noventa. Al igual que los countries, este modelo residencial también está cercado por un alambrado perimetral, es de acceso restringido y cuenta con personal de vigilancia. Sin embargo, se diferencian de sus predecesoras porque están destinadas al uso residencial permanente, así como a un mayor espectro de perfiles socioeconómicos, ocupacionales y generacionales. ${ }^{8}$

Pero cerrar los complejos residenciales no sólo se ha extendido en la periferia de la RMBA. A partir de los noventa se construyeron en el territorio de la CBA numerosos edificios de departamentos denominados en

\footnotetext{
${ }^{6}$ Maristella Svampa (2001) realiza un detallado análisis sobre la relación entre la clase media que pudo acomodarse e incluso ascender en el emergente contexto político-económico y la expansión metropolitana de las urbanizaciones cerradas.

${ }^{7}$ Guillermo Tella caracteriza las urbanizaciones cerradas de la RMBA como predios "parquizados de viviendas amplias y diseńo cuidado, separados físicamente del tejido circundante por medio de dispositivos de seguridad que han alterado el paisaje urbano: muros cerrados de gran altura a la manera de murallas, con puestos de vigilancia y sistemas de custodia a cargo de agencias privadas que ejercen un control permanente sobre las entradas y salidas de residentes, visitantes y trabajadores" (1999: 63). En el ańo 2001, Maristella Svampa calculaba que en la RMBA existían 434 urbanizaciones cerradas. Se estima que durante los noventa se construyeron en promedio 45 urbanizaciones cerradas por ańo. En la actual década esa cifra se redujo a menos de la mitad (Ciccolella y Baer, 2008).

${ }^{8}$ Véase Svampa (2001: 74-79).
} 
la jerga local torres jardin, edificios en torre o torres de vivienda. ${ }^{9}$ Se trata de un predio que puede llegar a ocupar toda una manzana (una hectárea) e incluye una o más torres de departamentos para uso residencial permanente. Además de estar delimitado por una reja y vigilado por cámaras y personal de seguridad, este complejo residencial suele contar con un espacio verde en el perímetro de los edificios, estacionamiento para autos (en algunas ocasiones subterráneo), sala de usos múltiples (sum), lavadero y, en algunos casos, alberca y juegos infantiles.

El primer ejemplar de este tipo de torre se edificó en 1967 en el barrio porteño de Belgrano; no contaba con reja perimetral, pero sí con jardín en su alrededor. Roberto Aisenson, el desarrollador de este emplazamiento, afirmaba que el "edificio se concibió con la idea de atraer habitantes de casas de los barrios residenciales que por entonces empezaban a ser víctimas de robos" (Tella y Welch, 2002: 10). En 1974, en el barrio de Palermo se construye la torre jardín en su máxima materialidad, es decir, con la reja perimetral. El éxito inmobiliario de este modelo residencial se basó en los sistemas de seguridad y el equipamiento deportivo (cancha de tenis y alberca). Pero fue a partir de los noventa cuando, junto con el aumento del delito y la sensación de inseguridad, se expandió fuertemente la demanda de esta modalidad habitacional, especialmente en los barrios de alto estándar como Recoleta y Núñez (Tella y Welch, 2002). Por su parte, Szajnberg (2001) no concuerda del todo con el supuesto de que estos desarrollos inmobiliarios se hayan destinado exclusivamente a los estratos de población de mayores ingresos. ${ }^{10}$

Independiente del análisis del perfil socioeconómico de estos consumidores inmobiliarios, lo cierto es que la expansión de la demanda de las torres se fundamenta, en gran medida, en la vivencia de un medio urbano acechado por el delito, el deterioro de su infraestructura y la presencia de la marginalidad urbana. Frente a estos malestares que produce la ciu$\mathrm{dad}$, los enclaves urbanos asociados a las urbanizaciones y los edificios cercados se perciben como alternativas residenciales confortables, seguras y hasta saludables.

${ }^{9}$ A diferencia de las urbanizaciones cerradas de las áreas suburbanas, las construidas en el área central de la ciudad no tienen denominación oficial, académica o legal. De acuerdo con Tella y Welch (2002), otros autores las denominan emprendimiento residencial en altura con equipamiento, emprendimiento residencial amurallado, torres country y urbanización cerrada en vertical. En este trabajo analizamos ciertas prácticas y representaciones de la vida cotidiana de los residentes de un complejo residencial de este tipo, las Torres de Abasto.

${ }^{10}$ A partir del análisis estadístico de una muestra heterogénea de 217 desarrollos residenciales, Szajnberg comprobó que "más de la mitad del total de emprendimientos registrados [...] se asocia principalmente con los sectores socioeconómicos medios” (2001: 3). 


\subsection{Imagen y sentido de fragmentos urbanos}

Las mismas condiciones que propiciaron el consumo de torres y urbanizaciones cerradas como estrategia habitacional, también explican la preferencia por otros enclaves y circuitos privados como respuesta a la negación creciente de las calles, las plazas y otros espacios públicos. Es decir, el valor atribuido a estos enclaves no es ajeno al ambiente urbano degradado e inseguro que los circunda. ${ }^{11}$ Para Jameson (1991) la fragmentación y el contraste que producen estas islas urbanas como estrategia de valorización responde a los cánones de la arquitectura posmoderna. Este autor considera que la arquitectura y el urbanismo tienen una importancia sin precedentes en la expansión de los negocios financieros e inmobiliarios y que, sin adquirir un estilo homogéneo y unificado, la arquitectura posmoderna hace de los emplazamientos urbanos una ciudad ensimismada que niega la totalidad donde se inscribe. Desde una perspectiva similar, Harvey considera que los diseñadores urbanos ${ }^{12}$ intervienen en los espacios como partes autónomas y disociadas entre sí. Por tanto, a diferencia del modernismo que modela el espacio según objetivos sociales, "el posmodernismo cultiva una concepción del tejido urbano necesariamente fragmentada [...] de acuerdo con objetivos y principios estéticos que no necesariamente se inscriben en un objetivo social englobante" (Harvey, 1990: 85). El shopping center es visualizado por Sarlo (1994) como el principal testimonio de la presencia de la arquitectura posmoderna en las ciudades actuales y, en relación con ello, como una ciudad diminuta que reúne todos los servicios necesarios, pero que no forma parte de un proyecto urbano más amplio. Desde esta tesitura, sostiene que en estas ciudades ensimismadas la historia no "plantea el conflicto apasionante entre la resistencia del pasado y el impulso del presente", sino que "es paradojalmente tratada como 'souvenir' y no como soporte material de una identidad y temporalidad que siempre le plantean al presente su conflicto" (Sarlo, 1994: 19).

El empleo de la historia como souvenir permite, a su vez, reflexionar acerca del modo en que la arquitectura posmoderna se apropia y resignifica los estilos y géneros del pasado. La heterogeneidad estilística y discursiva es, para Jameson (1991), una de las estrategias que dispone la arquitectura posmoderna (pastiche) para reinventar y manipular el pasado, es decir, para apropiarse al azar de sus estilos y otorgarles un sentido que nunca tuvieron. El mismo Harvey analiza la manera en que los diseña-

\footnotetext{
${ }^{11}$ Hace casi 20 ańos, Silvestri y Gorelik ya se referían a la irrupción de los centros comerciales, de negocios y de barrios altos como "pedazos de modernidad cuya condición primera es la misma existencia de tal 'marginalidad"' (1990: 24).

${ }^{12}$ Dice Harvey: "nótese que los posmodernistas no hacen proyectos sino diseños" (1990: 85).
} 
dores urbanos posmodernos mezclan y citan según su arbitrio estilos del pasado y de diferentes lugares del mundo para, según sostiene el autor, exaltar el éxito de la reconversión urbana, negar efectos sociales negativos asociados a este proceso y contribuir, por tanto, a la valoración del espacio urbano.

Son varias las reflexiones que pueden extraerse de las caracterizaciones que realizan estos y otros autores sobre la arquitectura posmoderna. Lo que interesa aquí destacar es que los procesos de renovación urbana involucran, además de cambios morfológicos y de usos del suelo, un tratamiento deliberado y cuidadoso de la imagen. Ambas dimensiones, las transformaciones materiales y simbólicas, afectan las representaciones que permiten a las personas valorar y atribuir diversos significados a las transformaciones urbanas.

El patrimonio histórico, cultural y arquitectónico es un recurso de fácil manipulación para renovar la imagen de los centros urbanos, de los cascos históricos y de las zonas bien ubicadas con establecimientos industriales y portuarios en desuso. El manejo del contenido patrimonial de estas áreas estratégicas responde a intereses económicos del presente que encuentran en el consumo de paisaje urbano un factor de valoración del suelo. Por tanto, ocupa el centro de interés de los agentes económicos del mercado inmobiliario, especialmente el de los propietarios y desarrolladores (o promotores). Para Zukin (1995), es en este proceso, que articula la dimensión cultural con la lógica de acumulación de capital, donde se pone en juego la dimensión más importante del fenómeno reconocido como gentrification. ${ }^{13}$ En su trabajo, el concepto de paisaje no sólo refiere al medio físico del espacio, sino también a las prácticas sociales y simbólicas que lo constituyen. En el estudio de caso que nos ocupa en este trabajo, veremos que el aggiornamiento de los ámbitos de consumo mediante referencias al patrimonio de un barrio porteño afecta las prácticas y representaciones del grupo de personas entrevistadas, interfiriendo incluso en sus decisiones de localización residencial. A la mejor usanza de la arquitectura posmoderna, la utilización de símbolos y géneros del pasado ha contribuido a garantizar el consumo de los nuevos usos residenciales, comerciales y de servicios propuestos en la reconversión de un área céntrica de Buenos Aires.

Pero los procesos de renovación urbana no se limitan únicamente a los cambios materiales y simbólicos del espacio y dejan, por tanto, otro tipo de marcas en la vida urbana. Junto con la construcción o restauración de los edificios, y con el replanteamiento de los usos del suelo, también

\footnotetext{
${ }^{13}$ En principio, este concepto se ha empleado para caracterizar el traslado de sectores medios a los barrios populares londinenses que experimentaban una renovación urbana. Sobre los usos y significados atribuidos a este anglicismo se puede consultar García Herrera (2001)
} 
suele modificarse la composición social de los usuarios y residentes del espacio en transformación. Este aspecto de la gentrification (quizás el de mayor reconocimiento) lo trabajó en los sesenta Ruth Glass, la socióloga británica a quien se le atribuye la autoría del término (Sargatal, 2000). ${ }^{14}$ Desde este punto de vista, el barrio que estudiamos en este trabajo no ha experimentado un remplazo total de la población preexistente. El enroque de habitantes ocurrió más bien a una escala micro (frentes de calles y fragmentos de manzanas), sobre todo en aquellos inmuebles que se encontraban ocupados de manera informal. Así, en sentido estricto no puede hablarse de una gentrification íntegra y completa, pero sí se puede decir que la llegada de nuevos consumidores inmobiliarios y de nuevos locales y centros comerciales modificó el paisaje del barrio por la afluencia de grupos sociales con mayor poder adquisitivo y diferentes prácticas de la vida cotidiana, que las de las familias que habitaban el barrio antes de comenzar su reconversión. Precisamente, parte de estos nuevos vecinos del barrio (los moradores del complejo habitacional construido más importante) son los que entrevistamos para explorar algunos principios que operan en las prácticas y representaciones que establecen con los habitantes del emplazamiento cerrado que habitan, y también con los vecinos del barrio. Por todo lo expuesto en este apartado, procuramos no limitarnos al tratamiento de estos ámbitos vivenciales en sus aspectos materiales, estéticos y funcionales, sino también explorar los sentidos atribuidos y evaluar en qué medida la dimensión simbólica de algunas intervenciones urbanísticas afectan las interacciones entre los moradores y usuarios del barrio. Este desafío nos exigió diseñar una estrategia teórico-metodológica que interpelara el significado que los residentes de las torres le atribuyen a las prácticas cotidianas de ellos, la de los otros, y a las intervenciones

\footnotetext{
${ }^{14}$ La autora estudió la renovación de los centros urbanos de los países industriales que, por la depreciación del suelo, poblaron durante el siglo xx hasta los setenta sectores sociales de bajos ingresos. La desinversión y desvaloración de las áreas centrales coexistió con un aumento de inversiones y la consecuente valoración del suelo en áreas suburbanas. Estas circunstancias provocaron un paulatino deterioro del equipamiento y la infraestructura de los barrios populares céntricos y, al mismo tiempo, el embellecimiento de los suburbios. El círculo vicioso entre desinversión, degradación y desvaloración de los centros urbanos alcanzó un nivel tal que la diferencia entre la renta existente y la que se podría obtener mediante el uso óptimo del suelo (de las actividades que podría soportar en términos económicos y normativos) fue tan amplia, que se generaron condiciones favorables para el inicio de la gentrification. Pero esta revitalización material y funcional de las zonas céntricas se acompaña de una lógica que parece ser inherente a la gentrification: el remplazo de la población preexistente por grupos sociales de mayor poder adquisitivo. La creación de un nuevo mercado de consumidores residenciales no necesariamente se produce con la sustitución de pobres por ricos. Este hecho le cuesta a la raíz etimológica del significante gentrification algunas críticas porque los nuevos ocupantes del centro no sólo pertenecen a la gentry (aristocracia). En efecto, la renovación urbana de las áreas centrales es especialmente atractiva para una fracción de sectores de ingresos medios. Bourdieu (2000) asocia a este grupo social a ciertas nuevas profesiones entre las que destaca a los intermediarios culturales (ejecutivos de turismo, diseñadores, periodistas, agentes de cine, moda, publicidad, decoración, promoción inmobiliaria, etcétera).
} 
urbanísticas y arquitectónicas que las afectan. Se considera que la importancia de este tipo de perspectiva radica en que las representaciones y usos del espacio urbano permiten analizar algunos principios que operan en la (re)producción de un determinado modelo de ciudad.

\section{La reconversión del barrio del Abasto}

\subsection{El crecimiento y deterioro de un barrio en torno a su mercado}

El barrio del Abasto es conocido por una buena parte de los porteños y por muchos que visitan la ciudad de Buenos Aires. Sea por su proximidad al centro o por sus diferentes connotaciones históricas, lo cierto es que esta área de límites difusos ${ }^{15}$ ocupa un lugar distintivo en el imaginario de quienes habitan y recorren la ciudad (figura 2). Asimismo, desde hace mucho tiempo goza de características muy propias. La necesidad de disponer de un centro de abastecimiento acorde con el crecimiento que atestiguaba la ciudad a finales del siglo XIX, impulsó que entre 1889 y 1893 se construyera el Mercado Abasto Proveedor. El Abasto se convirtió desde entonces en el núcleo de las actividades comerciales que dieron dinamismo al barrio. Y junto a la aparición de carretas, vendedores, almacenajes y talleres también se instalaron algunos conventillos, teatros, cines, cafés y fondas. Estos elementos marcaron al barrio con sello propio y lo convirtieron en uno de los símbolos asociados a lo porteño. ${ }^{16}$ Con el correr de los años el mercado incrementó su actividad adosando algunos terrenos aledaños y requiriendo la ampliación de su superficie cubierta. La necesidad de mayor superficie y un incendio que destruyó más de la mitad del mercado viejo, impulsaron en 1928 la construcción del Nuevo Mercado del Abasto que remplazó un importante sector del antiguo edificio. Se completó así "el conjunto de construcciones que permanecieron hasta el cierre del mercado" (Berjman y Fiszelew, 1984: 113). ${ }^{17}$

En octubre de 1984 se clausuró el Mercado de Abasto. El cese de actividades y su paulatino abandono se hicieron sentir entre los vecinos que habían participado de la vida barrial fomentada por el mercado. El efecto negativo inmediato de la interrupción del comercio fue la pérdida

${ }^{15}$ El término Abasto no figura en el mapa de los barrios porteńos. En 1982 un proyecto de ley trató de incluirlo en el trazado que delimita los barrios de la ciudad, pero este proyecto nunca se llevó a cabo.

${ }^{16}$ Berjman y Fiszelew (1984) destacan que entre las manifestaciones culturales y populares que se exhibían en las fondas, cafés y bodegones se destacaban la música y el baile del tango.

${ }^{17}$ Los inconvenientes financieros y los aspectos externos que producía el mercado por razones de higiene y de congestión de actividades en una zona tan céntrica de la urbe, impidieron que la obra se completara como estaba proyectada (cubrir la superficie total de la manzana en la que funcionaba el mercado viejo). 


\section{Figura 2 \\ Ubicación del barrio del Abasto en la Región Metropolitana de Buenos Aires}

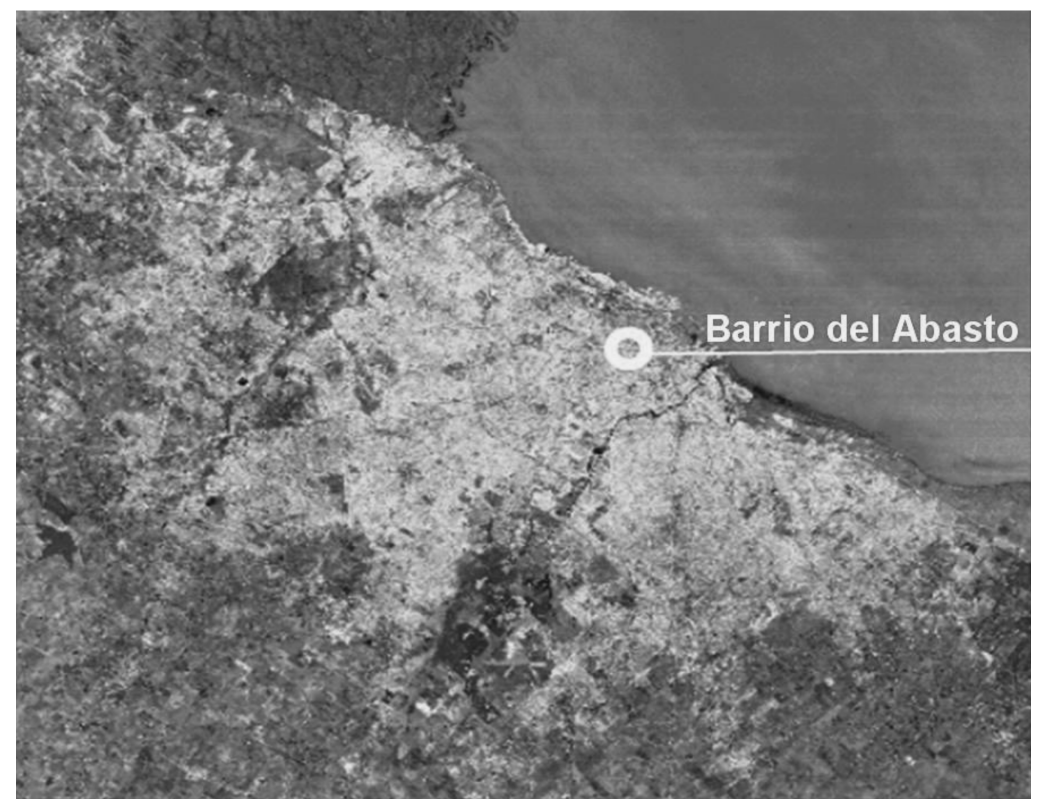

de trabajo de varias familias. Esto también provocó que se abandonaran casas, antiguos depósitos y algunas oficinas que luego ocuparon familias de bajos recursos, muchas de ellas provenientes de países limítrofes. Estos grupos sociales se convirtieron en el sector preferido para culparlo de los actos delictivos e indeseables que comenzaron a distinguir al barrio tras el cierre del mercado. Así, el barrio del Abasto se ganó el calificativo de área deprimida, el cual no remitía únicamente al deterioro edilicio y de infraestructura, sino también al escaso dinamismo de las actividades económicas, a la precariedad de las condiciones de vida de algunos de sus residentes y al peligro que representaba transitar por sus calles.

Los principales periódicos del país realizaron varios informes sobre el deterioro del barrio y el descontento de una parte de los vecinos. "Abasto. El Bronx porteño" se convirtió en uno de los titulares mediáticos preferidos para difundir una mirada sobre el barrio degradado: "Drogas, prostitución, sida, marginalidad, delincuencia [...] Desmantelado hace años el mercado, muchas casas abandonadas se han convertido en aguantaderos de malvivientes. La sensación de abandono y sordidez, como en un filme sobre el Bronx de Nueva York, sobrevuela la zona” (Clarín, 20/09/1994). La investigación periodística también se encargó de recoger diversos testimonios para transmitir el descontento de algunos vecinos: 
"Cuando funcionaba el mercado yo vivía puteando contra el ruido de los camiones [...] Pero hoy me doy cuenta que era toda gente de familia. Lo máximo que podías encontrarte era una pelea de changadores. Hoy la cosa cambió: está lleno de peruanos y bolivianos en casas tomadas".

Son varios los artículos y relatos que publicaron diarios y revistas. Pero la forma de abordar el deterioro del barrio es siempre la misma: los "ocupantes" cometen por ańadidura otras transgresiones a la ley, como el robo y la venta de drogas. Este desplazamiento de la ilegalidad también absorbe por inercia una tercera figura, la del inmigrante. Así, abandono, peligro, ocupante y peruano y boliviano fueron los significantes que vertebraron las representaciones sociales sobre el Bronx porteño. Otro informe periodístico muestra que estas estigmatizaciones alcanzan su máxima expresión en las dos áreas del barrio de peor reputación: la cortada Carlos Gardel y la calle Agüero, entre Guardia Vieja y la avenida Corrientes. A cada una de estas dos porciones del barrio le cabe una descripción, ${ }^{18}$ ambas acompañadas por un mapa que muestra la ubicación de las casas y los baldíos ocupados, donde destaca asimismo la ocupación del Chanta Cuatro, la antigua casa de tango frecuentada por Carlos Gardel para interpretar sus canciones (figura 3). El resto de la información que ofrece este mapa, titulado "Geografía del Abasto", repara en la actividad nocturna del barrio, especialmente la recreada por los bolivianos en los restaurantes y los locales para bailar.

A partir del cierre del Mercado del Abasto en 1984, se dieron a conocer algunos proyectos que promovían su acondicionamiento para desarrollar actividades comerciales y culturales. Estas propuestas debían ajustarse a las políticas urbanas que impulsaba el gobierno de turno. Una de las medidas exigía el traslado de las actividades de abastecimiento desde los mercados céntricos hacia el Mercado Central de Buenos Aires, ubicado en el partido de La Matanza del conurbano bonaerense. Asimismo, los proyectos de reciclado del mercado debían respetar las medidas que protegían el patrimonio arquitectónico. ${ }^{19}$

\footnotetext{
${ }^{18}$ El rasgo distintivo de las personas que residen en la calle Agüero se vincula con su condición de drogadictos y vendedores de drogas para el suministro del consumo personal. Se les presenta como un grupo social homogéneo que, si bien subsiste gracias a esta actividad ilícita, no reviste tanto peligro como los que habitan en la calle Carlos Gardel quienes, además de comerciar una mayor cantidad de sustancias ilegales, cometen delitos de mayor envergadura, como el robo a mano armada. En ambos casos, los de Agüero y los chicos de la cortada, son estigmatizados por la voz de un entrevistado que opera como discurso de verdad objetivando una supuesta homogeneidad de cada grupo.

${ }^{19}$ La primera medida fue la Ley de Abastecimiento del 15 de octubre de 1984, la cual establecía que "todas las actividades de aprovisionamiento se concentran en el Mercado Central y se establece el cese de estas funciones en todos los mercados de Capital Federal (Abasto, Dorrego, Saldías, entre otros) y del conurbano. En segundo término, la legislación relativa a la conservación de edificios y predios considerados patrimonio histórico urbano, legislación que se dicta y pone en práctica tanto a nivel nacional (a través de la Ley 12.665 y de la acción de la Comisión Nacional de Museos y
} 


\section{Figura 3 \\ La mirada de la prensa sobre el barrio deteriorado}

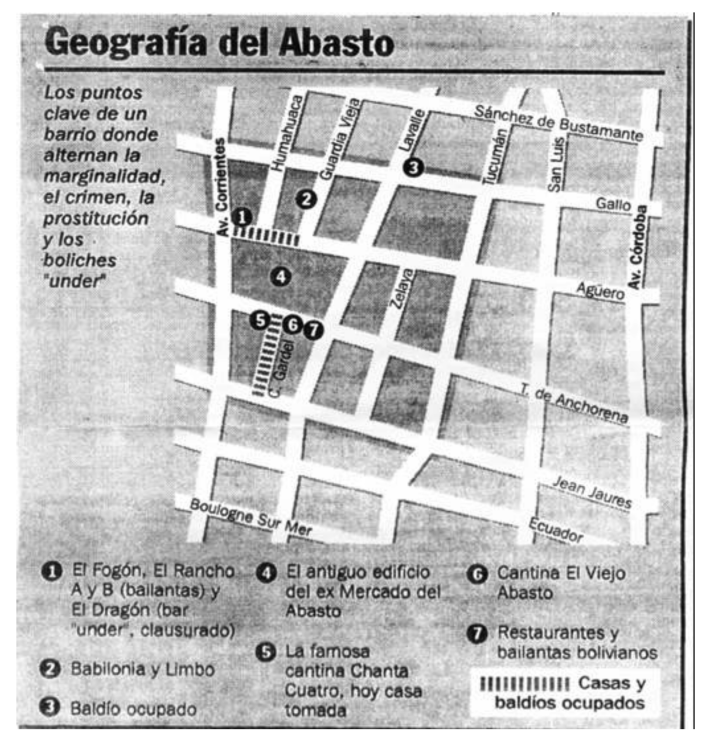

Fuente: Diario Clarin, 20/11/1994.

En este marco de políticas urbanas, a finales de 1984 el entonces intendente de la ciudad de Buenos Aires y el presidente de la Sociedad Anónima Mercado de Abasto Proveedor (samap) firmaron un convenio para transformar al antiguo mercado en "un conjunto cultural y comercial de gran nivel [donde] se construirá una plaza pública [...] un conjunto habitacional y de uso comercial, con espacios verdes de acceso público [...] se dona un terreno de 1,000 metros cuadrados para la construcción de una escuela" (Clarin, 28/11/1984, en Berjman y Fiszelew, 1984: 180).

A principios de 1986 la cooperativa El Hogar Obrero (ЕHO) obtuvo la mitad del paquete accionario de la asociación empresarial y se convirtió en copropietaria del extinto mercado. La cooperativa (que también era propietaria de la cadena de supermercados Supercoop y del mercado Spinetto y comenzaba su conversión a shopping center) tomó a su cargo el edificio del Abasto con el compromiso de preservar sus características arquitectónicas (Quintero, 1998: 7). Pero la envergadura de las inversiones requeridas, los problemas financieros de la cooperativa y la crisis político-económica que atravesaba el país a finales de los ochenta, impidieron que el proyecto se concretara. Ante la imposibilidad de revertir la

Monumentos y Lugares Históricos) como municipal, por intermedio de varias ordenanzas" (Quintero, 1998: 3). 
severa crisis financiera y la fuga de sus depositantes, la cooperativa anunció su quiebra en 1993. El shopping center Spinetto y el Mercado del Abasto eran los principales activos que la cooperativa EHO disponía para sortear la deuda con sus empleados, ahorristas y acreedores. En estas circunstancias el mercado se puso a la venta y transcurrieron dos años para que encontrara nuevo dueño.

\subsection{La reconquista del barrio}

En 1995 la empresa Inversiones y Representaciones Sociedad Anónima (IRSA), en asociación con la constructora Parque Arauco, compró el edificio que ocupaba el mercado del Abasto. ${ }^{20}$ Éste fue el primer paso del proceso de reconversión del barrio. Desde allí el grupo empresarial comenzó a expandirse mediante la compra de numerosas casas y terrenos aledaños al edificio del antiguo mercado hasta llegar a obtener, además de la extensa superficie donde se construiría el shopping Abasto, dos manzanas y cinco esquinas estratégicas; una de ellas correspondiente al edificio donde funcionaba el emblemático Chanta Cuatro.

La reconquista del barrio se planificó mediante la identificación de los dueños de las propiedades para proceder luego a su compra inmediata. Quizás una de las circunstancias más conflictivas que tuvo que afrontar IRSA fue el desalojo de las familias que habían ocupado las propiedades compradas por el grupo empresarial. La operación consistió en el pago en efectivo a los ocupantes para que de forma pacífica se desprendieran de las viviendas (Carman, 2006).

Una vez que se adquirió casi la totalidad de las cuatro manzanas comprendidas entre las calles Anchorena, Lavalle, Sánchez de Bustamante, Guardia Vieja, Agüero y la avenida Corrientes, el grupo empresarial APSA se hizo cargo de la transformación urbanística del barrio del Abasto, comenzando por la reconstrucción del edificio donde funcionaba el antiguo mercado mayorista (figura 4). Su espacio físico de casi $120,000 \mathrm{~m}^{2}$ se acondicionó para diversos usos ${ }^{21}$ y se impulsó con el objetivo de crear el

\footnotetext{
${ }^{20}$ Ambos grupos empresariales compraron $87 \%$ de las acciones de SAMAP, que luego reconvirtieron en Alto Palermo Sociedad Anónima (APSA). El 13\% restante lo conservaron algunos ex ahorristas de EHO. IRSA es una empresa de bienes raíces que, desde 1943, cotiza en la bolsa de Buenos Aires, y en la de Nueva York a partir de 1994. Por medio de esta empresa, el magnate mundialmente reconocido, George Soros, canaliza la mayor parte de las inversiones en bienes raíces en Argentina.

${ }^{21}$ La megaobra se inauguró en noviembre de 1998 y ofrece la siguiente infraestructura y servicios: 230 locales comerciales (repartidos en cinco niveles), dos subsuelos de estacionamiento para 1,300 vehículos, una plaza seca de $3,000 \mathrm{~m}^{2}$ cubierta por un techo de vidrio, un patio de comidas para 1,500 personas sentadas, 12 salas de cine en dos niveles con capacidad para 3,326 personas, un parque de diversiones con capacidad para 6,000 personas por hora y un centro de entretenimiento para niños llamado El Museo de los Niños.
} 


\section{Figura 4 \\ Principales intervenciones urbanísticas del barrio de Abasto}

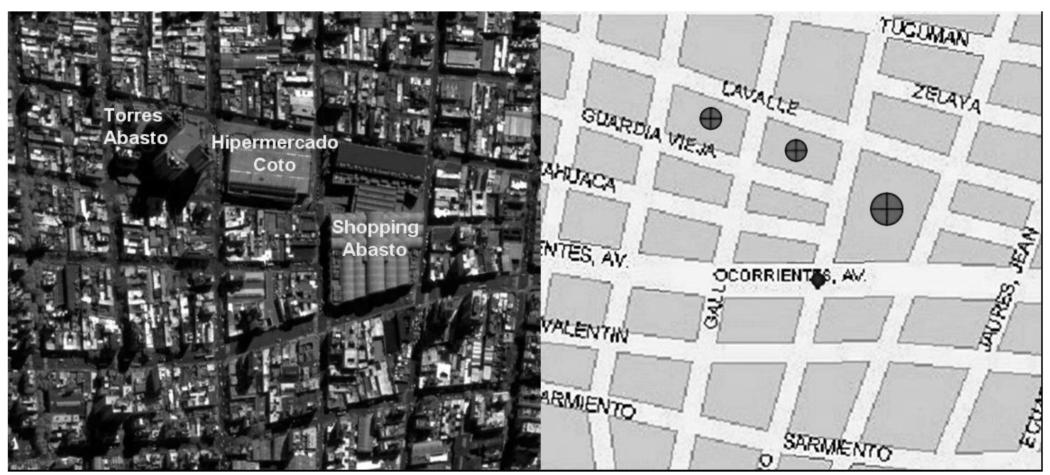

mayor centro comercial del país. Este gran centro comercial se dio a conocer como Shopping Abasto (sA).

De los 200 millones de dólares invertidos por APSA, aproximadamente un tercio se destinó a la compra del terreno y la edificación de las Torres de Abasto (TA). La construcción de las mismas comenzó en agosto de 1997, cuando el montaje del sa ya estaba avanzado. Se trata de un complejo residencial cerrado, con cuatro torres con 545 departamentos de dos, tres y cuatro ambientes. Para no desentonar tanto con la tradición tanguera del barrio, se decidió denominar a las torres Carlos Gardel, Astor Piazzolla, Enrique Santos Discépolo y Osvaldo Pugliese. El complejo habitacional dispone además de un jardín de uso común con alberca, solárium y un camino aeróbico que rodea al emplazamiento rejas adentro. También cuenta con juegos infantiles y un arenero. Las dos entradas a las torres las custodia personal de vigilancia que también circula al interior del condominio cercado. El cierre y demás dispositivos de seguridad completan los atractivos de las TA que, como veremos más adelante, son parte de los factores que orientaron la elección por esta modalidad habitacional. Los diarios más importantes del país y El Libro del Abasto ${ }^{22}$ anunciaron que $80 \%$ de las viviendas se vendieron a comienzos de 1997 en sólo dos semanas (cuando recién se excavaba el pozo), con un valor estimativo de 800 pesos/dólar el $\mathrm{m}^{2}$. Sin embargo, el correr del tiempo mostraría que el boom inmobiliario no fue tan exitoso. Un propietario de las TA y uno de los directores que tuvo a su cargo la construcción de las mismas aseguraron que alrededor de $35 \%$ de las ventas fracasaron porque varios potenciales compradores no reunían los requisitos de

\footnotetext{
${ }^{22}$ Publicación escrita por Tatar y Cunietti (1998) e ideada por la empresa IRsA para presentar las transformaciones urbanísticas que se emprendieron en el barrio.
} 
financiamiento. Asimismo, la crisis económica en las postrimerías de los noventa redujo significativamente la venta de departamentos. Todavía a principios de 2002, en una atmósfera de alta incertidumbre ante las versiones fatalistas sobre el devenir del recién devaluado peso, IRSA concretaba operaciones de venta con particulares que tenían su ahorro retenido en los plazos fijos por los bancos, fenómeno que se dio a conocer con el nombre de corralito. ${ }^{23}$

Cuando se construyeron los primeros cuatro pisos de las torres, IRSA decidió encarar la tercera intervención urbana en la manzana ubicada entre las TA y el sa. Se trataba de la construcción de un hipermercado que fue vendido a la sociedad Coto CICSA. ${ }^{24} \mathrm{Al}$ principio se proyectó construir un túnel aéreo que comunicara el hipermercado Coto con el sA. Por medio de un dibujo, El Libro del Abasto muestra que el conducto aéreo efectivamente se montó (figura 5). La ilustración también muestra otra vista panorámica donde éste se interpone de inmediato con dos torres emplazadas en la misma manzana donde funciona el ostentoso centro de compras. A diferencia del túnel, este complejo habitacional que empata en altitud con las torres vecinas y reales, no se menciona en el libro que ovaciona la transformación del barrio realizada por IRSA. ${ }^{25}$

En conjunto, estos tres grandes desarrollos urbanísticos (en adelante, eje TCs) constituyen los emplazamientos urbanos más destacados por las notas periodísticas y los informantes consultados. El efecto urbanístico de este corredor se acompañó por la apertura de 22 nuevas sucursales de bancos y numerosos desarrollos comerciales, inmobiliarios, gastronómicos y artístico-culturales. Desde el punto de vista territorial y funcional, se trata de una propuesta urbanística que detonó varias actividades y proyectos. ${ }^{26}$

La construcción del eje Tcs la celebró la mayoría de los vecinos que estaban indignados con el pasado reciente del barrio. Las calles deterioradas y percibidas como tierra de nadie empezaron a tener mayor circu-

${ }^{23}$ En abril de 2002 se publicó que "las constructoras que tienen departamentos para estrenar prefieren cobrar con plazos fijos al equivalente de la mitad de la cotización en dólares de diciembre, antes que tener los departamentos inmovilizados. Es el caso de IRSA, que tiene dos complejos de torres con departamentos a estrenar (Abasto y Torres Jardín): entre fines de febrero y comienzos de marzo recibieron cientos de consultas. Pero recién en las últimas dos semanas comenzaron a concretarse las primeras ventas con plazos fijos, según voceros de la empresa” (Clarín, 6/4/2002).

${ }^{24}$ El hipermercado cuenta con $56,000 \mathrm{~m}^{2}$ distribuidos en cinco niveles. En la primera planta se venden productos de supermercado (alimentos, artículos de limpieza, perfumería, etc.), en el piso superior artículos electrónicos, textiles y de mueblería, así como otros productos para el hogar. El estacionamiento tiene tres subsuelos con capacidad para 1,000 automóviles.

${ }^{25}$ Quien dirigió la construcción de las TA y del SA nos informó que el espacio aéreo sobre el hipermercado lo conservó IRSA con miras a construir otro complejo residencial, en este caso, compuesto por dos torres con una reducida superficie destinada a los usos comunes.

${ }^{26}$ Una caracterización de tales transformaciones se puede consultar en un informe que realizó el Cedem (2003) acerca de la transformación económico-territorial del barrio. 


\section{Figura 5}

\section{Versión oficial sobre la reconversión del barrio del Abasto}

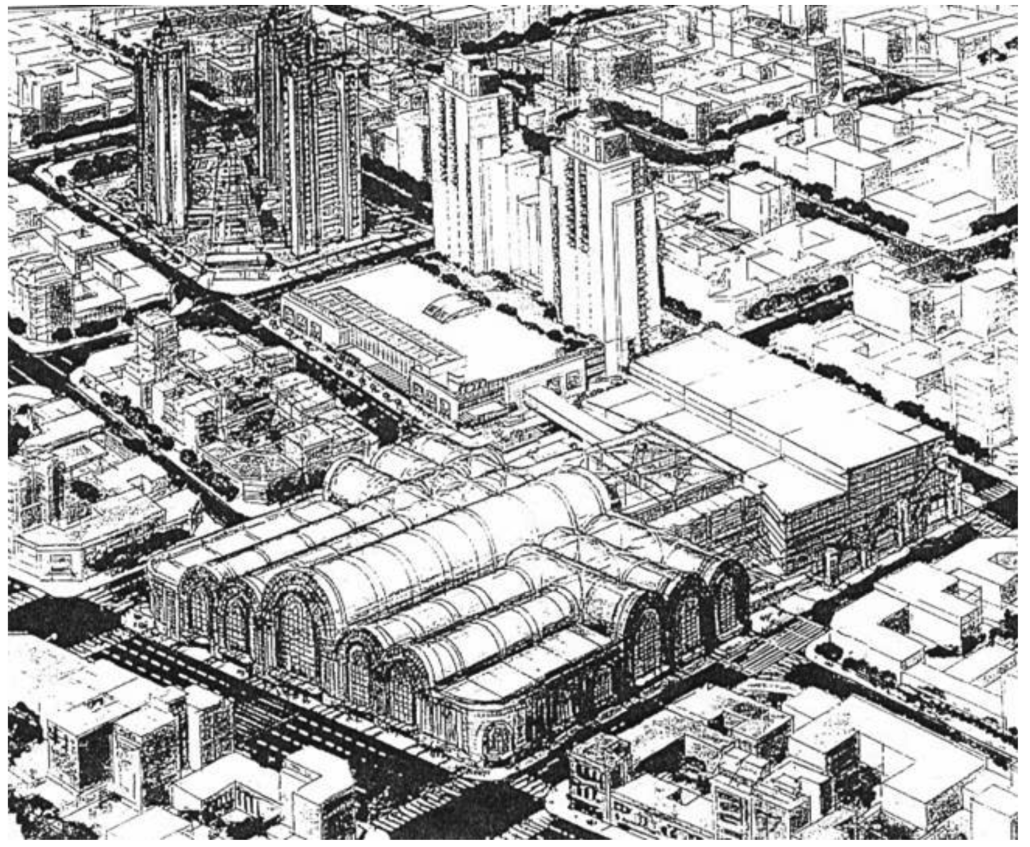

Fuente: Tatar y Cunietti (1998: 188).

lación de autos, peatones, así como más iluminación y presencia de la seguridad pública y privada. La calle Carlos Gardel también se incorporó al proceso de transformación urbana emprendida por IRSA y se convirtió en un corredor peatonal con nuevo alumbrado. El Chanta Cuatro ahora luce una fachada renovada y ofrece cena con espectáculo de tango por un costo que varía entre 90 y 180 dólares. Desde el 11 de diciembre de 1999, el restaurante es escoltado por un monumento que rinde homenaje al morocho del Abasto. ${ }^{27}$ La figura de Gardel también se hace presente en la calle Jean Jaures, en el 735, la casa chorizo que compartió con su madre entre 1927 y 1933, hoy convertida en la Casa Museo Carlos Gardel. Y la lista es larga... ¿dónde acaso no están Gardel y el tango en el barrio del Abasto ${ }^{28}$ Los restaurantes, las publicaciones barriales, los centros cultu-

${ }^{27}$ Precisamente, el día de nacimiento de Carlos Gardel y, por extensión, la fecha consagrada como el día del tango. El monumento, que costó 120000 pesos/dólares, es el primero que le rinde homenaje a Gardel en las calles de Buenos Aires, pues hasta la fecha el único que existía es el que aún custodia su tumba en el cementerio de la Chacarita.

${ }^{28}$ En el barrio vivieron también otros de los máximos exponentes del tango, como Osvaldo Pugliese, Aníbal Troilo y Astor Piazzolla. 
rales, las fachadas pinceladas por el fileteado porteño, el eje TCs, todos se apoderan de alguna huella tanguera que dejó el pasado por el barrio.

Pero toda apropiación del pasado, o más bien de algunos de sus fragmentos, se encuentra revestida por diferentes elementos del contexto del presente. Es aquí donde a la dimensión física y funcional de las transformaciones urbanas se le anexa una dimensión simbólica, en este caso relacionada con el tratamiento selectivo y reinventado del pasado. Esta evocación de reminiscencias históricas contribuye, a su vez, a la valoración inmobiliaria que conlleva la renovación urbana. Vicente Palazzo Caputo, hijo del martillero propietario de las bolsas de chauchas en el antiguo mercado, es uno de los dueños de la Inmobiliaria Palazzo Caputo que tiene a su cargo la venta de gran parte de las viviendas y terrenos de la zona. Poco antes de transcurrido un año de la inauguración del sA anunciaba: "Hay una gran especulación, en la calle Gardel hay propietarios que piden 200 mil dólares por terrenos que antes costaban 20 mil [...] antes, el Abasto era de clase media, media baja; hoy, por las torres, es de clase media, media alta" (Clarin, 11/07/1999). Un socio y familiar de Vicente, Octavio Palazzo Caputo, sostenía asimismo que "un lote que hoy cuesta 200 mil dólares, hace un año costaba 130 mil y hace diez, 50 mil. La zona residencial se extenderá desde Lavalle hacia Barrio Norte y antes del 2000 el Abasto será otro. Ya se están erradicando todas las casas tomadas. El olorcito a Bronx está por desaparecer. El Abasto se va a convertir en un barrio cinco estrellas" (Revista Tres Puntos, 15/07/1998).

\section{Autoimágenes y prácticas al interior de las Torres de Abasto}

Para explorar las prácticas y representaciones de la vida cotidiana de los residentes de las Torre de Abasto se realizaron entrevistas en profundidad. La implementación de esta técnica cualitativa de obtención de información no tuvo el objetivo de indagar la intimidad de la vida de los residentes de las torres, sino de rastrear un discurso que se elabora en un contexto social de significados compartidos. Para ello, utilizamos una guía sobre los temas a tratar en los encuentros con los entrevistados. Sólo algunas preguntas se pautaron antes de la entrevista, el resto de las intervenciones se realizaron según el relato de los entrevistados y los tiempos que ellos proponían. Las preguntas se formularon lo más neutralmente posible ${ }^{29}$ y la duración de los encuentros osciló entre una y dos horas, según la disponibilidad de tiempo de los entrevistados, el agotamiento de los temas y la reiteración de la información. Además evitamos preguntas retóricas que indujeran

\footnotetext{
${ }^{29}$ Evitamos emplear expresiones con connotaciones que pudiesen remitir alguna inclinación ética, política o moral.
} 
algún tipo de respuesta e intentamos que los entrevistados dieran rienda suelta a las verbalizaciones sobre sus perspectivas y experiencias.

Consideramos que las clasificaciones de grupos de entrevistados según género, edad y niveles socioeconómico y educativo no reproducen de manera necesaria y mecánica significados compartidos. Aun así, procuramos abarcar el espectro más amplio y variado del universo poblacional relacionado con nuestro estudio de caso: los residentes de Torre de Abasto. Realizamos un total de 18 entrevistas con 13 residentes (con cinco de ellos coordinamos dos encuentros, el primero en carácter de entrevistas exploratorias). El tamańo de la muestra no se determinó de antemano y el acceso a los entrevistados se fue generando mediante los contactos que ellos nos facilitaron con otros vecinos..$^{30}$ Decidimos terminar con las entrevistas cuando percibimos que los últimos encuentros no aportaban información adicional a los fines prácticos del problema de investigación, es decir, cuando la muestra cualitativa había alcanzado su punto de saturación.

El procesamiento de la información se efectuó atendiendo las siguientes precauciones metodológicas: 1) se consideró al análisis de los relatos como una herramienta privilegiada para reconstruir experiencias de vida ya consumadas; no fue la experiencia misma lo que se cuestionó, sino el sentido que los entrevistados tienen de su propia experiencia; 2) se utilizó la información obtenida mediante las entrevistas, no para rastrear evidencias y justificar así algún hecho o hipótesis, sino para reconstruir el sentido que los entrevistados comparten (o no) con otros moradores de las torres. Se procedió así a interpretar el contenido latente (antes que el explícito) de los relatos para identificar regularidades discursivas que permitieran explorar los sentidos socialmente compartidos que sostienen y organizan las prácticas y representaciones de la vida cotidiana de los residentes de las Torres de Abasto sobre el lugar que habitan y su área colindante.

Uno de los temas planteados en la entrevista fue el de las representaciones que construyen los residentes sobre el equipamiento de que disponen y los vecinos con quienes conviven al interior de las torres. A continuación se presentan algunos respuestas acerca de las percepciones relacionadas con las prácticas y maneras de relacionarse dentro del complejo residencial.

Una de las características de las urbanizaciones cerradas del tipo Torres Jardín es que disponen de espacios de uso colectivo (como la alberca y el jardín) que fomentan el acercamiento y los vínculos personales entre los residentes. Por tanto, estos lugares comunes también facilitan el intercambio de ciertas prácticas y representaciones.

\footnotetext{
${ }^{30}$ Además de permitir la puesta a prueba de la primera entrevista exploratoria, el primer entrevistado se convirtió en nuestro portero de campo, es decir, en el acceso al resto de los entrevistados.
} 
El tema del parque es como un núcleo, a partir de ahí hice muchos amigos (abogado, 48 años).

Siempre bajan con sus sillitas a tomar mate, se han armado muchos grupos de algún piso y de otro. Vida social abajo en el complejo hay, hay bastante (docente, 32 años).

Hay un parque, una pileta bastante grande [...] y en el parque hay una placita; generalmente hay mucha gente, los días de sol y fines de semana está lleno de chicos, a veces se parece a un club porque hay gente en malla subiendo en el ascensor (desempleada, 36 años).

Entre las condiciones que potencian aún más las posibilidades de establecer vínculos vecinales, se destaca el hecho de que la mayoría de los residentes de las TA tienen edades similares. La empatía generacional es un atributo relevante para compartir ciertos intereses y, por tanto, establecer una mayor afinidad.

Creo que es toda gente joven la que vive acá [...] y hay muchas parejas con chicos pequeños y ellos son los que se reúnen en la placita y siempre están juntos" (estudiante, 19 años).

Gente vieja no vi, los que vi están alrededor de los 30 y pico y 40 años, digamos de 35 a 45 años. Son más bien familias jóvenes, chicos de cinco o seis" (empleada administrativa, 38 años).

La mayoría somos matrimonios jóvenes con chicos o que estamos por tener; y hay también matrimonios con adolescentes" (docente, 32 años).

Fueron varios los informantes que distinguieron a los niños, adolescentes y adultos de hasta aproximadamente 50 años como los principales grupos de edades que habitan en las torres. En casi todas las ocasiones enfatizaron el rol de los niños como nexo entre los mayores. Del mismo modo, la cercanía generacional también se destaca entre las parejas de jóvenes que tienen bebés o niños de corta edad.

Además de cierta homogeneidad de grupos de edad, los entrevistados identificaron otro rasgo que comparte la población de las torres. Ante la pregunta abierta cómo son sus vecinos, la mayoría se refirió al nivel socioeconómico de quienes residen en las TA. Clase media fue el calificativo más recurrente. No todos adoptaron el poder adquisitivo de las familias como criterio de demarcación de clase, algunos prefirieron la comparación de las TA con otros complejos de torres. El siguiente relato pone de manifiesto este registro relacional.

Está claro que en cuanto al nivel social somos todos de una clase media, media de medio pelo. O sea media, media. Si vos fueses de clase media alta no comprarías acá, es un hecho. Son edificios lindos y departamentos lindos, pero son edificios normales. Si vos tenés plata no compras acá. ¿Porque viste que hay torres 
de clase media alta, las que están en Coronel Díaz, en Libertador y esas, no? (ama de casa, 42 años).

Este discurso también modera la relación directa que se hace de las torres de vivienda cerradas como una modalidad habitacional exclusiva para los sectores de altos ingresos. El comentario "Está claro que en cuanto al nivel social somos todos de una clase media, media de medio pelo", nos recuerda asimismo la caracterización que realiza Svampa sobre los countries y barrios privados considerados de baja jerarquí. Inspirada en Arturo Jauretche, la autora señala que "el concepto de 'medio pelo' alude a la imitación de pautas de conductas de grupos que se encuentran en lo alto de la escala social y se aplica por extensión a aquellos sectores de las clases medias y medias altas en donde confluyen la pretensión y la aspiración de apropiación de los símbolos de la consagración social" (Svampa, 2001: 132).

La ocupación laboral fue otro de los elementos que, junto a la pertenencia generacional y al nivel socioeconómico, los entrevistados identificaron para trazar similitudes entre los residentes de las TA. Sea por conocimiento fehaciente o por sentido intuitivo, el calificativo que más sobresalió para referirse a las ocupaciones laborales de los vecinos del complejo fue el de profesional.

En general son profesionales, bueno sé que mi amigo es economista, la novia es abogada, hay una chica que es odontóloga, otra abogada más, después hay un tipo que sé que es visitador médico [...] en general son jóvenes profesionales (médica, 29 años).

Sé que hay bastantes profesionales y de todo. No sé, yo no hablo mucho con la gente, pero eso escuchás un poco en las reuniones de consorcio (comerciante, 52 años)

Los cuatro tópicos recién mencionados favorecen la socialización de ciertas prácticas y representaciones de la vida cotidiana. Al configurar parte del nosotros de los residentes de las TA, los lugares comunes, las edades similares, el nivel socioeconómico y la ocupación laboral constituyen un lugar de pertenencia desde donde se elaboran juicios y atribuciones de sentido.

La apropiación colectiva del jardín, el parque o la placita se asocia a las actividades deportivas y los momentos de ocio como tomar sol, banarse en la alberca, hacer ejercicio físico y, en el caso de los niños, jugar en la plaza.

Lo que tiene agregado, digamos, es un sendero aeróbico, que es un caminito alrededor de todas las torres que es para que corras, camines, para que hagas gimnasia. Y se utiliza mucho, la gente lo utiliza mucho" [...] en verano podemos 
bajar e ir a la pileta como si fuera un hotel, parece un hotel cinco estrellas (peluquero, 52 años).

Pero en algunos casos el valor del equipamiento y los servicios se relaciona más con su valor de uso potencial que con su uso real y efectivo. La alberca y el parque ilustran este aspecto:

Pero iba a la pileta más antes que ahora. Y sí, porque parece mentira, pero el hecho de tenerla ahí [...] es como que la tenés, y si no voy hoy, voy mañana. Antes yo pagaba mi cuota del club y la aprovechaba más (diseñadora, 26 años).

Tiene la pileta que en realidad desde que nos mudamos acá nunca fuí, pero bueno, está ahí (empleada administrativa).

Independientemente del nivel y tipo de apropiación de los lugares comunes, consideramos que el valor atribuido al equipamiento de las torres manifiesta la importancia que adopta la naturaleza y el aire libre en las elecciones habitacionales de los moradores de las torres. Si bien estos espacios no tienen la misma amplitud y usos que las áreas comunes de las urbanizaciones cerradas de la periferia metropolitana (countries y barrios privados), el parque de las torres lo viven los vecinos como la posibilidad de tener un espacio verde para resguardarse del cemento de la ciudad.

Lo que se pone de manifiesto con este tipo de relato es la valoración que recae sobre lo que Svampa (2001) caracterizó como estilo de vida verde. La autora sostiene que la exaltación de este estilo de vida tiene una notable injerencia en los principios que orientan las prácticas habitacionales de ciertos sectores de la denominada clase media. El procesamiento de la información obtenida en las entrevistas permitió identificar tres tipos de prácticas asociadas a este estilo de vida: 1) el contacto con la naturaleza, 2) las actividades deportivas, y 3 ) las actividades de ocio.

Este estilo de vida lo difunden las inmobiliarias, los desarrolladores y diversos comunicadores mediante un discurso que apela al mejoramiento de la calidad de vida individual. Aquí no analizamos el entramado discursivo que los intermediarios culturales elaboran para orientar el consumo a esta modalidad habitacional, pero interesa subrayar la correspondencia que adopta la producción del discurso de estos agentes y las atribuciones de sentido que le otorgan los residentes de las TA a las prácticas habitacionales que pueden desarrollar en el complejo puertas adentro. El conjunto de los entrevistados manifestaron la importancia que tienen el contacto con la naturaleza, las actividades deportivas y de ocio en el mejoramiento de la calidad de vida.

Los entrevistados también se refirieron al enrejado y la seguridad como otra ventaja que ofrecen las TA. Se trata, desde luego, de una de las cualidades más visibles, aunque a veces más soslayadas, de este tipo de urba- 
nizaciones cerradas. Cualquiera que recorre el área percibe la tajante discontinuidad y aislamiento que establecen las torres respecto de su entorno a través del enrejado (también verde) y de los estrictos dispositivos de seguridad.

Para mí tiene todas las ventajas por lo que te digo, tiene pileta en el verano, un camino aeróbico que a mí me gusta mucho hacer deporte y lo puedo hacer. Es un predio que está cerrado totalmente con guardias, con dos lugares de guardias con circuito cerrado (peluquero, 52 años).

Hay más gente que por ahí piensa parecido a mí y que opta por estos lugares por una cuestión de seguridad, de tranquilidad, porque también es cierto que uno puede querer que los hijos crezcan con la mayor libertad mental posible (empleada administrativa).

Como que afuera no estás seguro y acá adentro sí, la gente [...] se siente libre, hay confianza y seguridad (abogado, 48 años).

La sensación de protección que ofrecen la reja y el personal de vigilancia se convierte en una condición necesaria para desarrollar aquellas prácticas que se asocian a un estilo de vida verde. Lo paradójico aquí es que la vigilancia y el enrejado se equiparan con tranquilidad y libertad. La contradicción de este fenómeno se suspende (parcialmente) cuando la vida libre y verde equivale a la sensación de resguardo frente a las amenazas e incomodidades que algunos residentes de las TA manifestaron percibir fuera de las torres. El límite que traza el enrejado y refuerza la vigilancia permite no sólo recluirse momentáneamente de un mundo urbano que se vive y percibe crecientemente como degradado, empobrecido y hasta peligroso, sino también ańadir un plus a la vida verde que los lugares comunes de las torres proponen. Desde este punto de vista, consideramos que el estilo de vida verde encerrada da un carácter singular (y a la valoración social) de estos enclaves urbanos.

\section{La apropiación del barrio en las prácticas de consumo}

Ahora abordamos parte de las representaciones que se construyen en las inmediaciones del complejo residencial de las TA. Al mismo tiempo, analizamos las formas en que los residentes de las torres se apropian cotidianamente de los lugares fuera del complejo que habitan.

Las TA pertenecen al barrio de Almagro, mientras que algunos lugares de su entorno se extienden a los límites del barrio de Balvanera. Pero los límites de los 47 barrios porteños son estrictamente formales y no determinan la jurisdicción de ningún tipo de función, sea ésta administrativa, política, fiscal o escolar. Para los moradores de las torres tampoco tienen importancia alguna. La mayor parte de ellos desconocen que tanto las TA como sus inmediaciones pertenecen a estos barrios oficiales, incluso al- 
gunos manifestaron no conocer la existencia de Balvanera. No ocurre lo mismo con el reconocido barrio del Abasto. Los residentes se inclinaron por éste para referirse al barrio de las torres y su área circundante. Si bien la extensión y los límites que los entrevistados le otorgaron al barrio del Abasto son bastante difusos (hecho que nos parece razonable tratándose de un barrio que no posee estatuto oficial alguno), varios de ellos coincidieron en que el corredor que traza el eje TCs conformaría el centro gravitacional del mismo (figura 3). No nos interesa determinar con precisión la concepción que tienen los moradores sobre los límites formales del barrio en que viven, sino más bien aproximarnos al barrio que viven. Abordaremos sí las prácticas y representaciones que los moradores de las TA establecen en las inmediaciones de las torres. Llamaremos barrio a estos ámbitos de uso cotidiano. Pierre Mayol sostiene que el barrio es "una organización colectiva de trayectorias individuales; es la distribución, para sus usuarios, de lugares de 'proximidad' en los cuales se encuentran necesariamente para satisfacer sus necesidades cotidianas" (1994: 13). Desde esta perspectiva, el barrio se traduce en una apropiación subjetiva que, partiendo de sus hogares, los moradores realizan a través de sus itinerarios. Estas trayectorias de la vida cotidiana se fundan en determinadas representaciones colectivas del barrio. $\mathrm{Y}$ a la inversa, las representaciones contribuyen a la producción y reproducción de los diversos usos del barrio. La reciprocidad entre las prácticas y representaciones barriales es lo que nos ocupa en este apartado.

El hipermercado Coto, el sa y el subte son los lugares del barrio que los moradores de las TA frecuentan a diario. Son las necesidades de transporte y, particularmente las de consumo, las que motivan el empleo cotidiano de estos ámbitos. Los comercios de la calle Corrientes se presentan como otra alternativa para salir de compras. Estos itinerarios nos dan otra pauta sobre las motivaciones que operaron en la elección de las TA como lugar de residencia. El predominio de estos usos del barrio también refuerza la importancia que tiene en la vida cotidiana el fácil acceso a los centros de consumo. No se trata sólo de estar más cerca de todo sino de disponer de todo en un mismo lugar. Esta concentración espacial de comercios permite reducir los tiempos muertos de desplazamiento.

Yo no camino mucho por el barrio, no salgo a caminar por acá, mis circuitos son el Coto, el supermercado. Todo las torres hace las compras en el Coto (analista de sistemas, 32 años).

Está bueno, necesitás algo y caminás por Corrientes y lo conseguís a dos pesos. Además tenés el centro comercial de once acá nomás (ama de casa, 42 años).

El acondicionamiento del espacio para agilizar las prácticas de consumo responde a una dinámica metropolitana que, desde hace aproxima- 


\section{Figura 6 \\ Vista de las Torres de Abasto y el hipermercado Coto desde las escalinatas del Shopping Abasto}

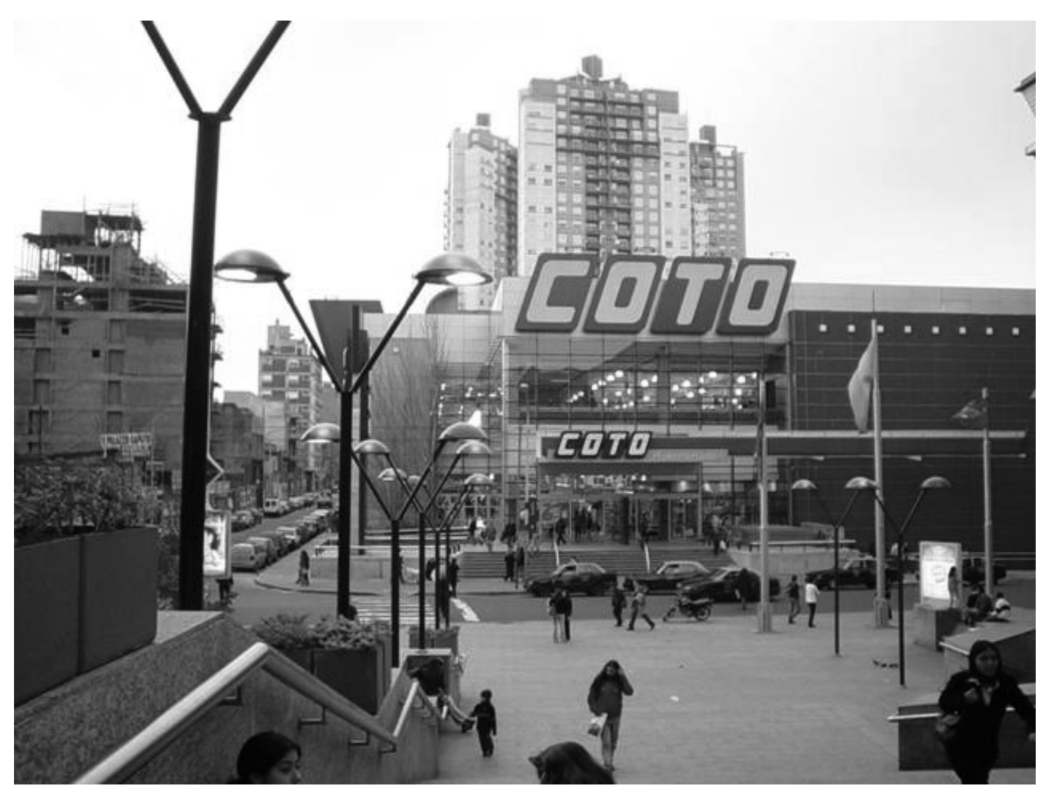

Foto: Luis Baer.

damente tres décadas, privilegia estas actividades en detrimento de otros usos. En este contexto de transformaciones urbanas, quizá sean los shopping centers y las cadenas de hipermercados sus principales monumentos. Sin embargo salir de compras no es la única práctica que se adueña de estos sitios urbanos. La apropiación del shopping también manifiesta otros usos colectivos.

Venimos al cine, por una cuestión que lo tenemos a una cuadra y podemos venir en cualquier momento: ché, en media hora dan una película, bueno vamos (diseñadora, 26 años).

Es muy práctico [...] incluso a veces vamos a tomar un café (médica, 29 años).

Las referencias a las tradiciones también encuentran un lugar en el barrio, especialmente mediante alusiones al pasado tanguero que contribuye a formar una imagen mítica del barrio. El sentido positivo y genuino que se le otorga a la historia se relaciona con las fachadas antiguas del barrio y el resurgimiento del principal baluarte tanguero, Carlos Gardel. 
La historia que tiene este barrio es impresionante. Yo creo que de a poco se está redespertando todo lo que fue "el Abasto", lo que sigue siendo, porque no es nada más historia, es el presente también. Además hace poco inauguraron el museo Carlos Gardel, todavía no fui, pero quiero ir esta semana (peluquero, 52 años).

A la cortada de Gardel la mejoraron muchísimo, pusieron un monumento y en la esquina con Anchorena hicieron un restaurante muy fino, el Chanta Cuatro se llama (comerciante, 52 ańos).

¿Vos viste lo que es la arquitectura de las casas? Aparte ahora hay varias que las están reciclando [...] es un barrio especial, es histórico (docente, 32 años).

La reinvención de la historia necesita algún tipo de tratamiento de los antepasados. La forma que asume esta relación, tan compleja como conflictiva, oscila entre una negación total de los bienes materiales y simbólicos preexistentes y una negación parcial que recupera y resignifica algunos referentes del pasado para incorporarlos a la actualidad. La segunda versión es la que compete al barrio del Abasto. Si bien los procesos de reinvención urbana se realizan de acuerdo con los requerimientos del presente, no son las mismas necesidades de activación patrimonial acá y allá, para unos y para otros. Se sabe que los intereses imbricados en la reconversión de un área estratégica son divergentes, cuando no antagónicos. Se establece así una lucha sobre los bienes, las imágenes y las prácticas del pasado que ameritan revivificarse. Como dice Tzvetan Todorov (1995: 47), "no son coincidentes los objetivos a los que se intenta servir con ayuda de la evocación del pasado". En suma, la controversia de qué, cómo y para qué recordar (el carácter selectivo de la memoria) atraviesa de lleno los procesos de renovación urbana de esta índole.

La llegada del sA es un acontecimiento atractivo para explorar una de las formas que adopta la reinvención de los recursos patrimoniales del barrio. Desde su inauguración en 1998, se multiplicaron las menciones sobre el pasado tanguero y el personaje mítico de Gardel. María Carman hace un estupendo análisis sobre este suceso político. Realiza una descripción de la manipulación del mito de Gardel durante el festejo inaugural: "Un Gardel tridimensional -al que se podía 'tocar' gracias a unos anteojos especiales- 'saludó' y 'bendijo' la recuperación del barrio para el Abasto y Buenos Aires, mientras enunciaba frases tales como: 'Al Abasto lo inventaron pero yo le di patente'. 'Cómo no voy a venir [a la inauguración del shopping] si yo soy el símbolo del símbolo”' (Carman, 2002: 6). Así, la invitación de Gardel a la inauguración tuvo el propósito de glorificar el barrio que vendría, o más bien, el que ya había llegado. Con ello se intentaba revertir el imaginario urbano que asociaba el Abasto con el Bronx porteño; con ello se intentaba erradicar una de las principales amenazas del negocio inmobiliario asociado a la valoración del suelo. De esta manera se procuró eludir toda referencia a la imagen del barrio abandonado, 


\section{Figura 7}

Monumento Carlos Gardel y restaurante y tanguería Chanta Cuatro, al lado del Shopping Abasto

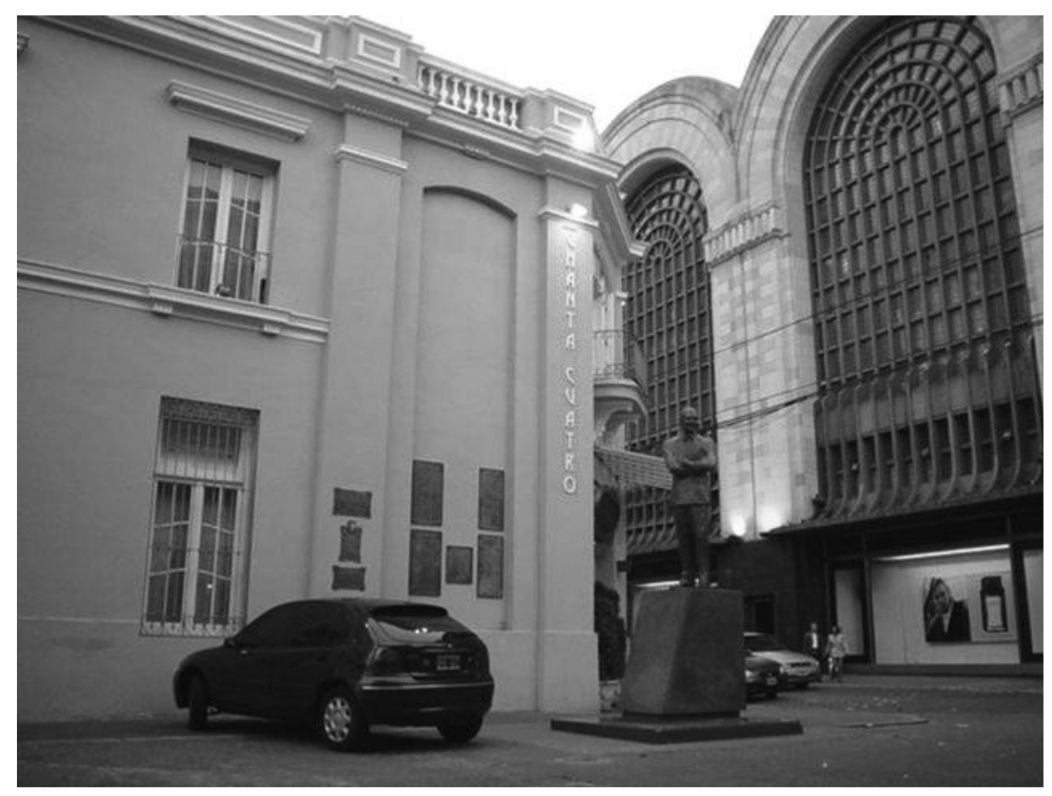

Foto Luis Baer.

afeado y peligroso que los medios de comunicación y usuarios de la ciudad le adjudicaban a las prácticas de los sectores más empobrecidos del barrio. El objetivo que le asignaron al morocho del Abasto en este proceso fue reconquistar un barrio usurpado por otros morochos, en particular los ocupantes de casas y terrenos. El shopping y Gardel quedaron así articulados en un juego de sentidos que negaba la anacronía (vaya si las hay) entre ambas figuras. La utilización de la figura de Gardel también contribuyó a desaparecer el interés económico de una corporación transnacional en torno a la conversión del Mercado del Abasto en uno de los centros de consumo más grandes de Argentina. En este sentido, el mítico Gardel permitió decorar con atributos locales dos aspectos en forma simultánea. Por un lado, al shopping center, quizás el sitio urbano más representativo de la expansión del consumo globalizado; por otro, al negocio encarado por Soros, uno de los referentes de la concentración del capital global.

El carácter de originalidad (lo único y lo auténtico) y exclusividad (lo nuestro) que le imprime Gardel al shopping se extiende sobre el resto del barrio. Esto se manifiesta en la restaurada calle peatonal que lleva su nombre y donde se encuentra su monumento. Debemos agregarles a ellos 


\section{Figura 8}

\section{Contraste entre las Torres de Abasto y las fachadas de las casas antiguas del barrio}

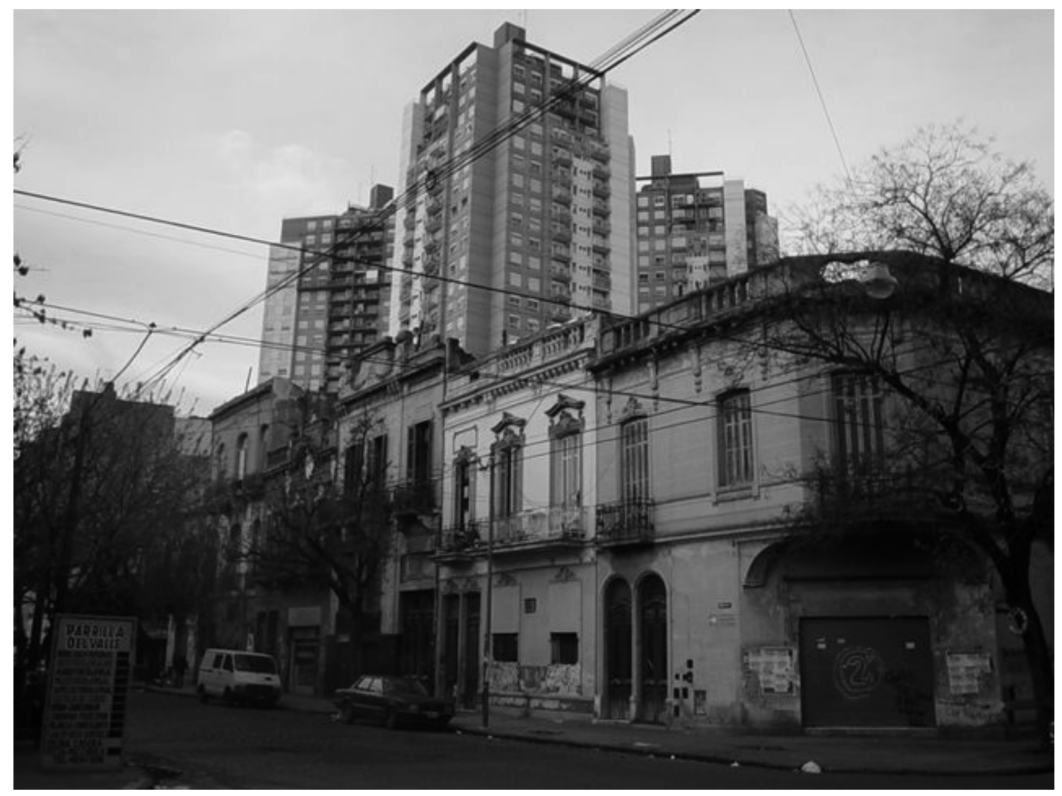

Foto Luis Baer.

el remodelado Chanta Cuatro. Con el correr de los años el tríptico calle peatonal-monumento-Chanta Cuatro se instaló en el imaginario de los vecinos del barrio, de los porteńos y los turistas que visitan la ciudad. El regreso de la figura de Gardel elevó así el puesto del barrio del Abasto en las preferencias del circuito turístico porteño.

El tratamiento de la memoria en la activación patrimonial del barrio facilita el análisis de cómo se materializa una determinada imposición ideológica. En este sentido, los aspectos negados por el proceso de patrimonialización (por ejemplo, la presencia de ocupantes ilegales, el interés económico de una empresa que realiza negocios inmobiliarios a escala global, el desalojo de los primeros efectuado por los segundos, el carácter globalizado de la reconversión de un barrio con atributos locales) pueden alcanzarse mediante la manipulación arbitraria de los personajes, las tradiciones y la historia de un barrio con el objetivo de sumar atractivos para promover el ingreso de nuevos grupos sociales, y así conformar un mercado de consumo que garantice las ganancias proyectadas sobre la reconversión del nuevo barrio. Pero no deja de llamar la atención cómo se manifiesta la negación de la pobreza y la marginalidad en este proceso. 
Las casas tomadas llegan incluso a percibirse como un elemento atractivo del paisaje urbano. Así lo expresa uno de los entrevistados:

A mí me gusta la estética de las casas tomadas. Hay cuadras que me hacen acordar a La Habana vieja y como que me gusta esa onda (empleada administrativa, 38 años).

En este caso, las fachadas de las casas se inscriben en una visión que traduce su deterioro en algo bello, genuino y hasta pintoresco. Pero de nuevo opera una negación. Cualquier reparo sobre las precarias condiciones de vida y edilicias de los moradores de estas viviendas queda, en este deslizamiento de sentido, parcialmente abolido. El significado que en ocasiones se le atribuye a las porciones del barrio aún intactas, se inserta en un campo discursivo que privilegia el consumo visual del paisaje por sobre las condiciones de vida de los habitantes.

La recuperación del espiritu bohemio del barrio también se puede reflexionar desde la perspectiva recién desarrollada. Durante las entrevistas las menciones sobre lo histórico se deslizaban discursivamente hacia la riqueza cultural, hacia la cantidad y variedad de actividades y espectáculos artísticos que el barrio ofrece. Sin embargo, la mayoría manifestó no haber concurrido a los ámbitos artístico-culturales del barrio. De hecho, el conocimiento sobre la oferta cultural resultó ser llamativamente precario.

Sé que hay centros culturales, de danza, pero yo particularmente no he ido. E inclusive está al lado de la casa del queso el no se qué Studio [...] es un centro cultural que no me acuerdo quién es la mujer esta, una artista, no me acuerdo, nunca fui $[\ldots]$ por lo general por acá no me muevo tanto (ama de casa, 42 ańos).

El barrio tiene una onda medio bohemia, está lleno de teatros y lugares artísticos. Eso lo hace lindo. Siempre intentamos hacernos un espacio para ir, pero siempre volvemos tarde (analista de sistemas, 32).

Al igual que para gran parte de la llamada clase media, existe una fuerte identificación con lo cultural. Se trata de algo que, independientemente de su significado, resulta digno de valorarse y poseerse. Cualquier actividad u objeto que se articula con él adquiere casi de manera automática prestigio. Lo cultural se presenta así como un objeto de deseo unido a un imperativo categórico. Sin embargo, no se traduce en prácticas concretas. En todo caso, su apropiación se limita (¡nuevamente!) a una práctica de consumo visual.

Las prácticas y referencias sobre lo histórico y lo cultural junto a los componentes del estilo de vida verde (el contacto con lo natural, las actividades deportivas y el uso del ocio) y de las autoimágenes (los lugares comunes, las edades similares, el nivel socioeconómico y el rango ocupacional) nos dan un marco de interpretación sobre las prácticas y repre- 
sentaciones que los entrevistados establecen dentro y fuera de las TA. Unos refieren a la ventajas de vivir en la torres, otras a las ventajas de vivir el barrio. Sin embargo, como ocurre al interior del complejo residencial, el barrio también despierta disconformidad y, en ciertas ocasiones, rechazo.

\section{El otro urbano en los itinerarios y las prácticas barriales}

La fractura que propone el eje TCs respecto de sus inmediaciones la mencionaron de manera permanente los entrevistados. Fractura real (vivida) y fractura imaginaria (percibida), en ambos registros se fija un contraste, un barrio escindido. A cada parte le corresponden diferentes modos de transitar y de relacionarse, es decir, diferentes modalidades de apropiación del espacio. Cada parte, por tanto, se piensa de maneras diferentes, a veces mediante significados opuestos.

Quizás está medio abandonado, más allá de lo que es el Abasto, que es un shopping súper, después las calles están medio hechas bosta, no sé, las veredas, hay pozos, como que hay ciertos lugares del barrio que están bastante dejados, pero después por el lado comercial está todo bien, te brindan de todo

Bueno, nosotros estamos justo acá muy pegados al shopping y al supermercado, pero te metés un par de cuadras un día a las 10, 11 de la noche y es inseguro.

La oposición es elocuente. Mientras algunas calles del barrio se perciben cómo inseguras y degradadas, el eje TCs representa lo contrario. Desde este registro relacional parece inevitable pensar el abandono y la inseguridad de las calles del barrio independientemente del contraste que fijan estas grandes intervenciones urbanísticas. ${ }^{31}$

Así, el uso del barrio requiere ciertos itinerarios para no transitar por lugares indeseados. Uno de los objetivos de los recorridos es evitar encuentros con personas que generan algún malestar $y$, en ocasiones, temor. Estas zonas del barrio tienen límites precisos y las reconocen todos los residentes de las TA.

Tengo por dónde moverme y por dónde no. Por ejemplo, por Agüero no vengo. Lo más probable es que no te pase nada, pero una vez que te pasó, te pasó (desempleada, 36 años).

Cuando volvía de la facultad, que volvía como a las 11:30 de la noche, a veces era bajarme del colectivo y estas dos cuadras que me tenía que caminar desde Córdoba hasta Lavalle, a veces caminaba corriendo porque el ambiente alrededor es un poco áspero, no es muy seguro, es como que acá adentro uno se siente seguro pero afuera, caminás una cuadra por Lavalle y es terrible lo que ves (diseñadora, 26 ańos).

${ }^{31}$ Véase el apartado 1.3. 
Yo siempre veía determinadas personas ahí sentadas y muy borrachas y son las que coincidentemente hacen de campana, o lo que sea, cuando están robando un auto. Entonces como en cualquier barrio vos aprendés a moverte, sabés que aquella esquina es peor que esta, o está más iluminada o menos iluminada (ama de casa, 42 años).

El saber táctico que orienta los desplazamientos por el barrio también tiene al shopping y el hipermercado como lugares de paso, no sólo para evitar el encuentro con personas que representan algún tipo de malestar o amenaza, sino también por el ambiente cerrado y la seguridad que ofrecen. De este modo, algunos residentes de las torres prefieren los recorridos por estos grandes centros de consumo antes que el empleo del espacio público del barrio.

La salida del subte de Carlos Gardel sale al shopping, y yo por el shopping de noche puedo salir. Tomo el subte de acá [estación Pasteur, próximo a su lugar de trabajo] hasta Carlos Gardel, salgo al shopping, lo atravieso todo, cruzo la calle, porque voy por la salida de Agüero, cruzo Agüero y salgo al Coto. Entro al Coto y salgo por la salida de allá que da a mi casa. O sea que voy calentito en invierno y frío en verano, me viene al pelo (peluquero, 52 años).

El cartografiado cognitivo que se construye sobre los contrates reales del barrio afecta las prácticas y representaciones de los residentes de las torres. Los grandes centros comerciales, ciertas fachadas arquitectónicas y los espacios culturales son bien ponderados y motivan ciertos procesos de identificación. Pero, al mismo tiempo, el barrio presenta espacios y personas que generan algún tipo de distanciamiento. Existen condiciones objetivas sobre las cuales se construyen estos sentidos opuestos. La indagación sobre las condiciones de las personas que generan malestar facilitó el análisis de una otredad constituida a partir de la estigmatización de ciertas personas y grupos sociales.

Siempre trato de tomar un taxi. Más de una vez me ha pasado que vengo caminado y hay mucho villero, mucho borracho, muchos pibes tomando que por ahí está todo bien, no pasa nada, pero eso te genera un poco de... no sé, muchas fiestas así de peruanos, yo que sé, te da un poco de cosa (estudiante, 19 años).

No sé si serán chorros o no sé qué harán para ganarse la vida, ni idea, pero no creo que sea gente que haga daño, ¿entendés?, no los veo peligrosos, no me dan miedo, pero prefiero no pasar por ahí (docente, 32 años). 


\section{Figura 9}

\section{Hipermercado Coto. Los grandes centros comerciales se utilizan para ir de compras y también para evitar las calles del barrio}

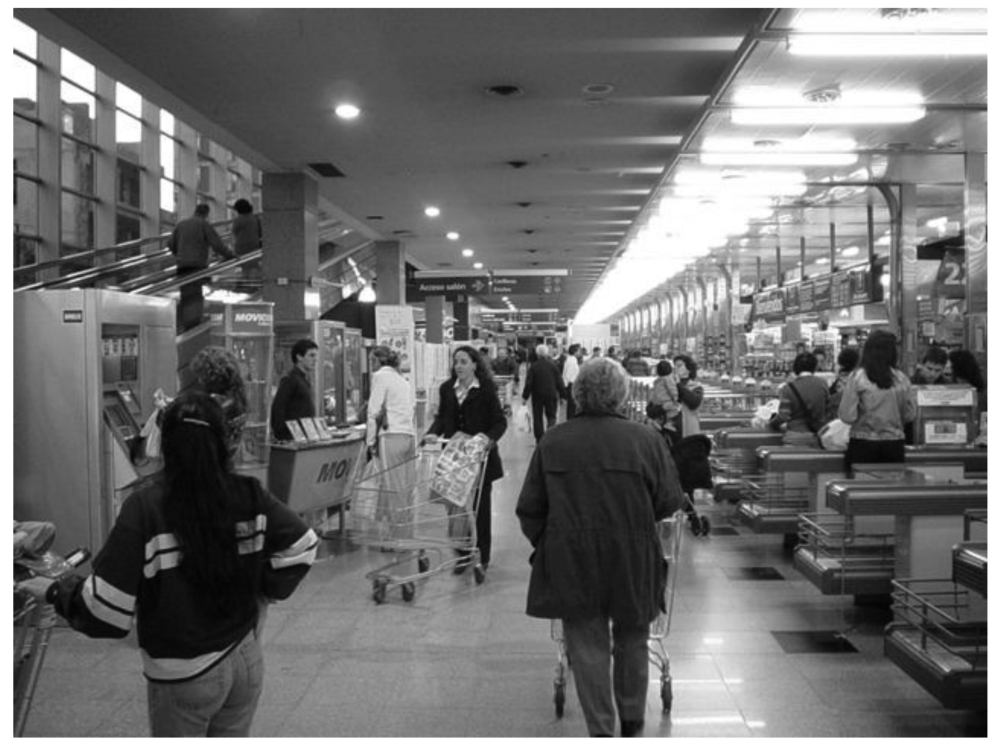

Foto: Luis Baer.

La descripción de las condiciones de vida de las personas que generan miedo o desagrado ponen en evidencia la marginalidad urbana que existe en el barrio. Nos referimos con ello a los excluidos del mercado laboral y de las redes de contención social; un universo poblacional que involucra a desempleados, pero sobre todo a los sectores más marginados como mendigos, familias carentes de vivienda digna, trabajadores ambulantes e informales, quienes se inclinan por el alcohol y otras drogas, los que pertenecen a alguna minoría étnico-racial y, en consecuencia, padecen situaciones de agresión física y simbólica, y aquéllos que por estas y otras razones cometen delitos y contribuyen así a reproducir el círculo de la violencia urbana. ${ }^{32}$ Además de ocasionar temor, incomodidad o algún otro atributo que genera distanciamiento, la condición marginal del otro

${ }^{32}$ En Marginalidad urbana en el próximo milenio, Löic Waqcuant (1999: 167-188) realiza una breve pero consistente caracterización de lo que entiende por nuevo régimen de marginalidad urbana. Se trata de una miseria modernizada que se origina principalmente en las grandes ciudades y de acuerdo con cuatro lógicas estructurales: 1) una dinámica macrosocial: el resurgimiento de la desigualdad social; 2) una dinámica económica: la mutación del trabajo asalariado; 3) una dinámica política: la reconstrucción de los Estados de bienestar; y 4) una dinámica espacial: concentración y estigmatización. 
urbano también provoca sensaciones ambiguas que oscilan entre la culpa y la comprensión.

Es como que hay un contraste bastante grande ¿̨no? Porque hay gente que está
muriéndose de hambre afuera del Abasto y hay gente que está haciendo shopping
en el Abasto, al lado, y creo que la gente de adentro del shopping está tan acos-
tumbrada como los de afuera, y no se vinculan, como tampoco yo me vinculo
con ellos (abogado, 48 años).
Ellos tienen los problemas de un montón de gente, que se están muriendo
de hambre, que no tienen mucha opción más que vivir así, no pueden elegir otra
cosa (docente, 32 años).

El malestar también puede asociarse con la irrupción de un otro urbano que actualiza constantemente el antagonismo social y su creciente polarización. En este punto, queremos trazar un paralelo con Zizek cuando sostiene que la exclusión constituye un síntoma inherente al funcionamiento del sistema político-económico actual: "Las 'excepciones' actuales -los sin techo, los que viven en guetos, los desocupados permanentes- son el síntoma universal del capitalismo tardío; constituyen la evidencia permanente, en aumento, que nos recuerda cómo funciona la lógica inmanente del capitalismo tardío" (Zizek, 1997: 176-177). Para entender el sintoma es necesario detenerse en el énfasis en el término excepciones, pues la imposibilidad de concretar los derechos básicos universales suele cuestionarse como una contingencia coyuntural y no como un elemento constitutivo del capitalismo tardío. Para Zizek, sostener el sintoma como estado de excepción es una condición necesaria de la reproducción del sistema capitalista de producción.

Retomemos ahora nuestro análisis, pero a partir de esta impronta teórica. Si el sintoma constituye un elemento que niega la satisfacción de necesidades elementales, podríamos sostener ya no sólo que el otro urbano no adquiere un lugar material ni simbólico en el proyecto de reconversión del barrio del Abasto, sino que también son ellos quienes, mediante su presencia y prácticas barriales, impiden la realización del embellecimiento urbanístico. Esta tensión se origina de un modo singular en el barrio del Abasto, una porción de la ciudad considerada estratégica y, al mismo tiempo, "social, económica y culturalmente degradada". ${ }^{33}$ En estos términos, la transformación del barrio supuso también un cambio de la composición social. ${ }^{34}$ Como vimos, este proceso requirió el desalojo de los ocupantes por parte de la empresa que tuvo a cargo la remodelación del barrio. Sin embargo, aún persisten algunas viviendas

${ }^{33}$ La expresión corresponde a un funcionario del gobierno porteńo en 1996 (tomada de Carman, 1998: 9).

${ }^{34}$ Véase el apartado 1.3 . 
ocupadas en las inmediaciones de los ámbitos más cómodos y seguros para desplazarse por el barrio: el eje TCs. A pesar de la resignificación de las fachadas como recurso paisajístico, la incomodidad que genera el otro urbano es más fuerte. Además de que se pone en evidencia la parcialidad del embellecimiento del barrio, también se manifiesta el carácter selectivo y excluyente de esta modalidad de reconversión urbana.

Entre quienes representan la otredad también debemos agregar a los peruanos, mencionados por todos los entrevistados. En su mayoría no llegan a ocasionar temor, pero de todas maneras se les vincula con la condición de ocupante ilegal, razón más que suficiente para sentir rechazo. En otras ocasiones, los perciben como un consumidor normal que usa los grandes centros comerciales, e incluso como un comerciante (también normal) que tiene un negocio en el barrio.

Lo que sí hay muchísimos peruanos, muchísimos, muchísimos, muchísimos. No te digo que estén todos en casas tomadas, porque todas las casas no tienen porque estar tomadas por los peruanos, pero los ves mucho en las calles, en el Coto, lo ves una barbaridad. Le digo a mi marido, vamos a hacer una prueba: "veamos en toda esta cuadra si no escuchamos peruano", y no, nunca (ama de casa, 42 años).

Se ve mucho peruano, sí, eso es cierto, aunque se ve mucho menos que hace un tiempito atrás. Se ve que con la situación económica del país se fueron yendo. Pero bueno, han puesto algún negocio por ahí, algún restaurante, alguna verdulería, se ve alguna peluquería (peluquero, 52 años).

La construcción y reconocimiento del otro urbano también se relaciona con el modo en que se apropian de las zonas del barrio que habitan o frecuentan.

Vas caminando y hay un montón de casas tomadas [...] ves un montón de gente en la calle, hay una calle que es Lavalle que está toda como ocupada con colchones, sillas, borrachos y mucha gente ciruja (analista de sistemas, 32 años).

A mí lo que me molesta en cualquier ámbito es la delincuencia. No sólo seguridad para mí, sino seguridad para todos. Acá en Agüero, en la otra cuadra entre Lavalle y Tucumán, ahí hay varias casas tomadas y hay una que es terrorífica, inclusive mis padres viniendo para acá, para comprar a Coto, vieron cómo asaltaban un auto [...] asaltaban, asaltaban, no, le sacaban el estéreo dos chiquitos que salían de las casas (desempleada, 36 años).

Así, las casas tomadas se proyectan como uno de los lugares donde la presencia del otro adquiere en el barrio mayor visibilidad. Los entrevistados mencionaron con exactitud la ubicación de estas viviendas. En el primer relato la irrupción del otro se manifiesta mediante la apropiación de la vereda con objetos o prácticas que producen malestar. Este uso de la vereda y la calle se da sobre todo en verano, cuando las familias de estas viviendas procuran espacio y aire para aliviar el calor. Y nuevamente lo 


\section{Figura 10 \\ Pasaje Carlos Gardel. Las casas antiguas tomadas persisten en las áreas del barrio de mayor transformación}

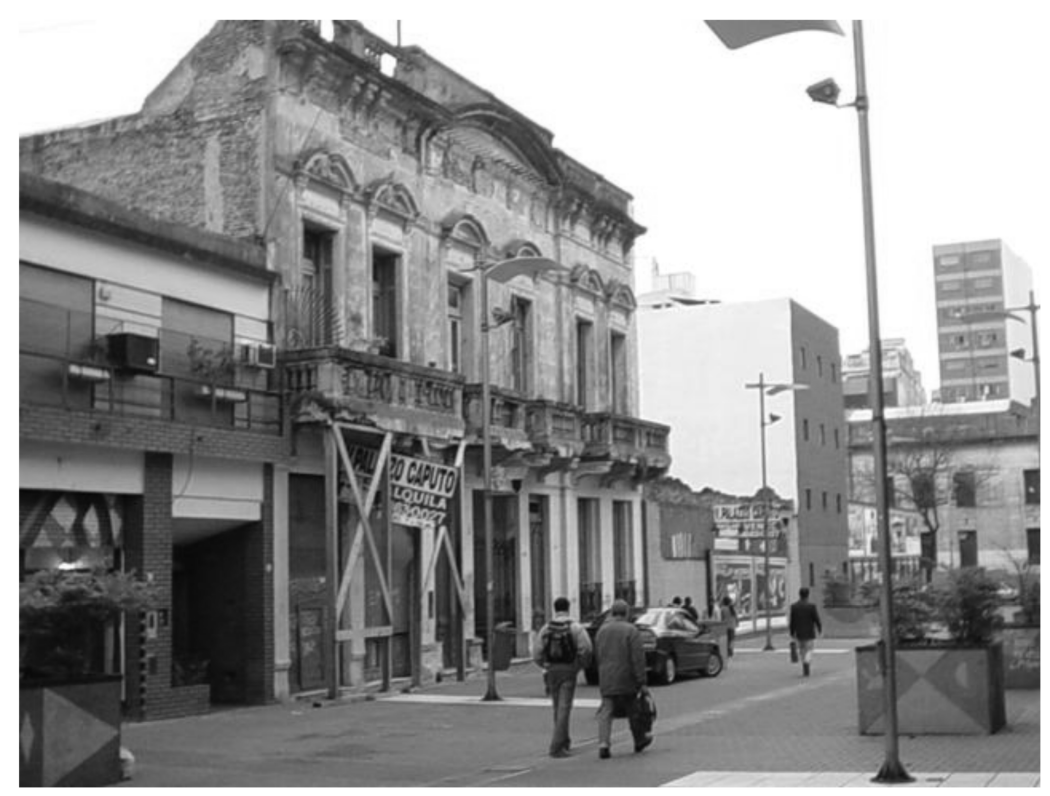

Foto: Luis Baer.

que perturba es la puesta en escena de las condiciones de vida que existen cruzando la cerca de las torres. El segundo relato establece (otra vez) una asociación directa entre los ocupantes de las casas y ciertas transgresiones a la ley, como el robo de equipos de audio de los automóviles, peleas callejeras o estados de ebriedad en la vía pública. La condición de ocupantes ilegales basta para culpar a estas personas de la usurpación de bienes privados y la transgresión del orden público.

Pero los tipos de usurpación no se restringen a estas dos modalidades (del espacio público y los bienes privados). Una entrevistada nos transmitió su indignación con respecto al deterioro de las condiciones arquitectónicas de los edificios antiguos que producen los ocupantes ilegales.

Hay muchas casas que no sé hasta dónde las podés conservar del todo, inclusive quedan fachadas y nada más [...] del otro lado está todo destruido, se viene todo abajo [...] y muchas de esas casas están tomadas, entonces la gente adentro no tiene el respeto que tendría que tener, entonces viven 30 personas y eso se va destruyendo y se les va cayendo todo lo que es mampostería, yesería y lo que sea (comerciante, 52 años). 
En este caso, el otro urbano también es responsable de la usurpación del patrimonio arquitectónico. Nuevamente, el papel que desempeñan los grupos sociales más vulnerables del barrio es el de vedar el pretendido embellecimiento del barrio en relación con el patrimonio arquitectónico.

\section{Palabras finales}

Fueron varias las inquietudes teóricas presentes en el desarrollo de esta investigación. Dos de ellas se pueden sintetizar mediante las siguientes preguntas: ¿qué vínculos existen entre las intervenciones urbanas y las prácticas y representaciones de los grupos sociales afectados por ellas?, y ¿qué estrategias teórico-metodológicas se pueden elaborar en este tipo de estudio?

Nuestra investigación se centra en el barrio del Abasto por la envergadura de los cambios urbanísticos que experimentó en los últimos años. La construcción y la remodelación de algunos emplazamientos modificaron la imagen, la fisonomía y los usos del mismo. Queremos retomar tres aspectos de este fenómeno.

- Primero: entre los principios que orientaron las transformaciones urbanas se destaca el interés por obtener una ganancia extraordinaria a partir del valor inmobiliario. Como vimos, la operación no tiene nada de misterio. Se puede resumir mediante la fórmula compra-acondicionamiento-venta. Se trata de la puesta en valor de suelo urbano considerado estratégico. Por su proximidad al centro, pero también por el valor patrimonial tangible (arquitectónico) e intangible (caracterizado aquí como lo histórico y lo cultural). Ahora bien, estos elementos fueron necesarios, aunque no suficientes, para la reconversión del barrio y el consiguiente negocio inmobiliario.

- Segundo: la modificación de la estructura y usos del barrio tuvo que acompañarse de un cambio de la imagen para captar ciertos patrones de consumo habitacional, de servicios y comercios. Los cambios de usos de suelo generados por la renovación urbana fomentó el arribo al barrio de nuevos habitantes y visitantes. Pero la afluencia de nuevos grupos sociales y actividades tuvo, como contrapartida, la expulsión de otras familias. La reinvención de un nuevo ámbito urbano trajo consigo la recomposición social del barrio. En suma, la generación de un mercado de consumo fue otra de las condiciones necesarias para comenzar esta reconversión urbana. 
- Tercero: sobre la reinvención material y simbólica del espacio urbano se reformularon los modos de vivir, pensar y vincularse con el barrio... y sus usuarios.

En un nivel más específico de nuestro estudio de caso, investigamos las formas de apropiación del espacio de uno de los grupos que protagonizó el proceso de recomposición social del barrio. En concreto, reconstruimos algunos principios que regulan las prácticas y representaciones de los residentes de las TA, específicamente los relacionados con el sitio que habitan y el barrio que lo rodea. Los diversos relatos que interpretamos fue una manera de aproximarnos a la pluralidad de percepciones, interacciones y estrategias que manifiestan la apropiación material y simbólica de estos espacios de uso cotidiano. Así exploramos un tipo de experiencia urbana con la complejidad de sentidos (compartidos y diferenciados) que la sostienen y constituyen.

Varios razonamientos permanecen aún inconclusos. No tenemos la intención, ni está a nuestro alcance, darlos por terminados. En esta instancia inicial, pero no definitiva, queremos retomar no obstante dos reflexiones sobre la elección de las torres como modalidad habitacional.

Los entrevistados transmitieron la experiencia cotidiana de lidiar con un barrio fracturado. Por un lado, el eje Tcs percibido como un ámbito seguro, cómodo y práctico. Por otro, algunas zonas adyacentes a las torres se ven como inseguras, feas y abandonadas. Nos preguntamos si acaso este contraste contribuye a que se polarice el sentido otorgado a cada uno de estos ámbitos, si frente a las experiencias de malestar que se viven en el barrio, no se exacerba aún más el estilo de vida verde encerrada que las TA posibilitan (la reja, la seguridad, lo natural, el deporte y el ocio); y a la inversa, si las condiciones habitacionales de las torres no refuerzan aún más el miedo o desconfianza inicial que se le tiene a los excluidos del consumo de esta propuesta de reconversión urbana. Creemos que esta línea de análisis también sirve para pensar el auge de las urbanizaciones cerradas como parte de un modelo de ciudad excluyente.

Entre los componentes que operan en la valoración del espacio asociada a este tipo de reconversión urbana vale destacar, por último, el mejoramiento de la calidad de la infraestructura y los servicios urbanos, pero también el consumo de una arquitectura del espectáculo que se sirve de la manipulación de objetos de alta cotización simbólica (como lo 
histórico y lo cultural) para ańadir valor y elevar la renta urbana. Esta forma de reinventar los recursos patrimoniales procura sobredimensionar el éxito de la reconversión urbana y garantizar la valoración inmobiliaria, de la cual, por cierto, varias familias que vivían en el barrio antes de su transformación no se beneficiaron.

\section{Bibliografía}

Abasto Plaza Hotel Buenos Aires. The tango experience (2004), folleto informativo, avenida Corrientes 3190, Buenos Aires.

Aldea. Revista exclusiva de Torres de Abasto (2004-2002), publicación mensual de distribución gratuita, números varios <www.geocities. com/aldeaabasto>.

Berjman, Sonia y José Fiszeles (1984), El Abasto. Un barrio y un mercado, Corregidor, Buenos Aires.

Borja, Jordi y Manuel Castells (1997), Lo local y lo global. La gestión de las ciudades en la era de la información, Taurus, Madrid.

Bordieu, Pierre (2000), Las estructuras sociales de la economía, Manantial, Buenos Aires.

Carman, María (1998), "El barrio del Abasto, o la invención de un lugar noble", Jornadas de Cultura Organizadas, Area de Cultura del Instituto Gino Germani, Universidad de Buenos Aires, noviembre.

Carman, María (2002), "Una mirada antropológica sobre un evento político: la inauguración del Shopping Abasto de Buenos Aires", III Jornadas de patrimonio intangible, El espacio cultural de los mitos, ritos, leyendas, celebraciones y devociones, Centro Cultural San Martín, Buenos Aires, agosto.

Carman, María (2006), Las trampas de la cultura. Los “intrusos" y los nuevos usos del barrio de Gardel, Paidós, Buenos Aires.

Ciccolella, Pablo (1999), "Grandes inversiones y dinámicas metropolitanas. Buenos Aires: ¿ciudad global o ciudad dual del siglo xxI?", Seminario de la Red Iberoamericana: Globalización y Territorio, Toluca, México. 
Ciccolella, Pablo (2006), "Metrópolis latinoamericanas: ¿`territorios subregulados, espacios del capital?”, en Adrián Aguilar (coord.), Las grandes aglomeraciones y su periferia regional. Experiencias en Latinoamérica y España, Conacyt-HCD-UnAm-Porrúa, México.

Ciccolella, Pablo y Luis Baer (2008), "Buenos Aires tras la crisis: ¿̨hacia una metrópolis más integradora o más excluyente?”, Ciudad y Territorio, Estudios Territoriales, XL, 158, Ministerio de Vivienda de España, Madrid, pp. 641-660.

Ciccolella, Pablo e Iliana Mignaqui (2008), "Metrópolis latinoamericanas: fragilidad del Estado, proyecto hegemónico y demandas ciudadanas. Algunas reflexiones a partir del caso de Buenos Aires", Revista Cendes, año 25, 69, Universidad Central de Venezuela, Caracas, pp. 47-68.

Clarin (1994), "Abasto, el Bronx porteño", Buenos Aires, 20 de noviembre, pp. 2-5.

Clarin (1999), "El abasto bajo la lupa", suplemento Arquitectura, ingeniería y planeamiento, Buenos Aires, 11 de enero, pp. 4-5.

Clarin (2002), "Compra de departamentos: mucha demanda poca oferta”, 30 de marzo. http://www.clarin.com/diario/2002/03/29/e01001.htm.

García Herrera, Marina (2001), "Elitización: propuesta en español para el término gentrificación”, Biblio 3W. Revista Bibliográfica de Geografia y Ciencias Sociales, vi (332), Universidad de Barcelona, Barcelona, http://www.ub.es/geocrit/63w-332.htm (consulta 27/07/2010).

Gorelik, Adrián (1994), "La ciudad de los negocios", Punto de Vista, 50, Buenos Aires, pp. 14-19.

Harvey, David (1990), La condición de la posmodernidad. Investigación sobre los origenes del cambio cultural, Amorrortu, Buenos Aires.

Informe económico del Cedem (2003), "La actividad económica en la Zona del Abasto: un balance de las transformaciones en la última década. Informe de actividad comercial del Abasto", Buenos Aires, 
<www.cedem.gov.ar/areas/des_economico/cedem/pdf/estudios_ especiales/abasto_dic_2003.pdf>.

Jameson, Frederic (1991), El posmodernismo o la lógica cultural del capitalismo tardío, Paidós, Barcelona.

Mayol, Pierre (1994), "Habitar", en Michel de Certeau, Luce Giard y Pierre Mayol (1999), La invención de lo cotidiano. 2. Habitar, cocinar, Universidad Iberoamericana, México.

Quintero, Silvina (1998), "Los lugares y los símbolos. Imágenes y sentidos de los shopping centers de Buenos Aires en los medios de prensa", Sincronia, Revista de Estudios Culturales de América Latina, Universidad de Guadalajara, Guadalajara, pp. 1-14.

Pírez, Pedro (2006), "La privatización de la expansión metropolitana en Buenos Aires", Economía, Sociedad y Territorio, vi (21), El Colegio Mexiquense, México, pp. 31-54.

Revista Tres Puntos (1998), "Abasto, muerte y resurrección”, 55, Buenos Aires, pp. 66-71.

Sargatal Bataller, Alba (2000), "El estudio de la gentrification", Biblio 3 W. Revista Bibliográfica de Geografía y Ciencias Sociales, Universidad de Barcelona, Barcelona, 3 de mayo, http://www.ub.es/geocrit/ b3w-228.htm.

Sarlo, Beatriz (1994), Escenas de la vida posmosderna. Intelectuales, arte y videocultura en la Argentina, Planeta, Buenos Aires.

Sassen, Saskia (1991), La ciudad global: Nueva York, Londres, Tokio, EUDEBA, Buenos Aires.

Svampa, Maristella (2001), Los que ganaron. La vida en los countries y barrios privados, Biblos, Buenos Aires.

Szajnberg, Daniela (2001), "Guetos de ricos en Buenos Aires: de la producción de la 'Ciudad de Masas' al consumo de la 'Ciudad Carcelaria', Mundo Urbano, 13, Universidad Nacional de Quilmes, Buenos Aires, http://mundourbano.unq.edu.ar/index.php?option $=$ com_content $\&$ view $=$ article $\& i d=101 \&$ catid $=88$. 
Silvestri, Graciela y Adrián Gorelik (1990), "Paseo de compras: un recorrido por la decadencia urbana de Buenos Aires", Punto de Vista, 37, Buenos Aires, pp. 23-28.

Tatar, Julio y Arnaldo Cunietti Ferrando (1998), El Libro del Abasto, Buenos Aires, Nuevo Milenio.

Tella, Guillermo (2000), "Efectos de una modernización tardía en la Región Metropolitana de Buenos Aires", en Área. Agenda de Reflexión en Arquitectura, Diseño y Urbanismo, 7, fadu-uba, Secretaría de Investigaciones en Ciencia y Técnica, Buenos Aires.

Tella, Guillermo y Max Welch Guerra (2002), "Importando la periferia a Buenos Aires. Urbanizaciones cerradas en la ciudad consolidada", Ciudad en cuestión. Nuevos Lugares, viejos espacios, Coloquio Internacional, Cátedra Walter Gropius-FADU-UBA-DAAD, Buenos Aires, octubre.

Todorov, Tzvetan (1995), Los abusos de la memoria, Paidós, Barcelona.

Veltz, Pierre (1994), "Jerarquías y redes en la organización de la producción y el territorio", en G. Benko y A. Lipietz (eds.), Las regiones que ganan, Edicions Alfons el Magnanim, Valencia, pp. 281-301.

Wacquant, Loïc (1999), "Marginalidad urbana en el próximo milenio", en Loïc Wacquant, Parias urbanos. Marginalidad en la ciudad a comienzos de milenio, Manantial, Buenos Aires.

Zizek, Slavoj (1997), "Multiculturalismo o la lógica cultural del capitalismo tardío", en Fredric Jameson y Slavoj Zizek (eds.), Estudios culturales. Reflexiones sobre el multiculturalismo, Paidós, Buenos Aires-Barcelona-México.

Zukin, Sharon (1995), The Cultures of Cities, Blackwell, Cambridge.

Recibido: 25 de junio de 2007. Reenviado: 19 de noviembre de 2009. Aceptado: 26 de noviembre de 2009.

Luis Baer. Es candidato a doctor por la Facultad de Filosofía y Letras de la Universidad de Buenos Aires. Es licenciado en geografía por la Univer- 
sidad de Buenos Aires; maestro en economía urbana por la Universidad Torcuato Di Tella y se especializó en políticas y mercados de suelo urbano en el Lincoln Institute of Land Policy. Actualmente es becario de investigación del Consejo Nacional de Investigaciones Científicas y Técnicas (Conicet) y profesor de geografía económica en la Universidad de Buenos Aires. Sus temas actuales de investigación son los procesos de reestructuración metropolitana, la segregación territorial, el acceso a la vivienda y el funcionamiento de mercados de suelo urbano. Entre sus publicaciones recientes destacan: "Precio del suelo, actividad inmobiliaria y acceso a la vivienda. Algunas reflexiones sobre el caso de la ciudad de Buenos Aires luego de la crisis de 2001-2002", Ciudad y Territorio, XL (156), Ministerio de Vivienda de España, Madrid, pp. 345-359 (2008); "Crecimiento económico, mercado inmobiliario y ausencia de política de suelo. Un análisis de la expansión del espacio residencial de la ciudad de Buenos Aires en los 2000", Proyección, 2 (5), Instituto de Cartografía, Investigación y Formación para el Ordenamiento Territorial (СіFOT), Mendoza, 4, 2 (5) (2008), revista virtual en coautoría, "Buenos Aires tras la crisis: ¿hacia una metrópolis más integradora o más excluyente?, Ciudad y Territorio, xl (158), Ministerio de Vivienda de España, Madrid, pp. 641-660 (2008). 